TERRITORY OF ALASKA

DEPARTMENT OF MINES

Report

of the

\title{
Commissioner of Mines
}

for the

BIENNIUM ENDED DECEMBER 31, 1950 
Leo H. Saarela, Commissioner of Mines, Box 2811, Juneau Howard M. Fowler, Associate Mining Engineer, Box 2811, Juneau Wiley D. Robinson, Associate Coal Mining Engineer, Box 2139, Anchorage

James A. Williams, Associate Mining Engineer, Box C, College A. E. Glover, Engineer-Assayer, Box 1408, Ketchikan John J. O'Shea, Assayer, Box 2139, Anchorage

Daniel A. Jones, Assayer-Engineer, Box 657, Nome

Donald J. Cook, Assayer-Engineer, Box C, College R. L. Stewart, Administrative Assistant, Box 2811, Juneau Jonna L. Flint, Stenographer-Clerk, Box 2811, Juneau

\section{Honorable Ernest Gruening \\ Governor of Alaska \\ Juneau, Alaska}

Sir :

I have the honor to submit to you, and through you to the Twentieth Session of the Territorial Legislature, in accordance with Section 47-3-119, ACLA, 1949, the report of the Commissidner of Mines for the biennium ended December 31, 1950.

Respectfully yours,

LEO H. SAARELA,

Commissioner of Mines. 


\section{CONTENTS}

Letter of transmittal .........
The Department of Mines ...me
Administrative and general information
Field investigations
Safety inspections
Assay and field offices

The mining industry

Future and needs of the industry

Placer mining

First division

Second division

Third division

Fourth division

l Mining

Matanuska field

Homer field

Point Barrow field

Healy field

Future and needs of the coal mining industry

Lode mining

oduction

Table I-Mineral production of Alaska, 1948-1950

Tabie II-Yearly average prices-1949-1950

ployment and accidents at mines

Table III-Employment at Mines, 1914 to 1950, inclusive

Table IV-Summary of accidents and employment at mines in Alaska, 1949-1950 
Table V-Summary of man-shifts worked, fatal and non-fatal accidents, and time lost in all mines in Aiaska

\section{8}

List of mining operations in Alaska, 1950

List of reports issued by Commissioner of Mines and corresponding pre-

ceding officials

\section{ILLUSTRATIONS}

Intelligiant developed by John Miscovich, stacking tailings at lower end of sluices, Tony Zimmerman operation on Independence Creek, Circle

district

Strandberg \& Sons washing plant on Utopia Creek, Fort Gibbon Precinct -Tanana district

Surface plant of Evan Jones Cool Company

Stripping overburden on Bed No. 1 by hydraulic giant-Usibelli Coal Company, Healy River, Healy coal field

\section{THE DEPARTMENT OF MINES}

\section{Administrative and General Information}

The Territorial Department of Mines, with headquarters at Juneau, operates four public assay offices and field stations in the Territory. The activities of the Department are directed by the Commissioner of Mines whose staff during the biennium consisted of an associate mining engineer at Juneau, an associate mining engineer at College on the University of Alaska campus, one associate coal mining engineer at Anchorage, three assayers located at Ketchikan, Anchorage and College, an assayer-engineer at Nome, and an administrative assistant and a clerk-stenographer at Juneau headquarters. The Commissioner also acts as District Mining Supervisor, under cooperative arrangement with the Department of the Interior, in the supervision of operations on coal leases and permits.

Commissioner of Mines B. D. Stewart, who had long served in that capacity with distinction, retired on January 1,1950 in accordance with the Public Employees Retirement Act of 1949, and Leo H. Saarela was appointed as his successor on the same date.

Funds were made available during the 1949 legislative session for operating the Nome office and it was reopened in June of that year. Several shifts of personnel took place, and repairs and other improvements were made in facilities at the Ketchikan and College offices. Funds appropriated by the 1949 Legislature for construction of offices at Anchorage, Fairbanks and Nome were frozen by the Board of Administration and no new facilities became available during the biennium, although the need, especially at Anchorage, was great.

Information on mining matters and mineral resources was furnished to those interested at the field and assay offices and furnished to those inters. Much information has been amassed in the Juneau files on various properties in the Territory by encineers of the Department. Libraries of Alaskan publications issued by the U. S. Geological Survey and the U. S. Bureau of Mines are also available for consultation at the various offices. The pamphlet on prospecting in Alaska that was originally issued in 1944 was revised and reprinted for the second time in Novemker, 1949 due to the demand for this type of information. Several thousand inquiries with regard to the mining industry by visitors and by correspondence were answered during the 
biennum. More than 4,000 publications were distributed during the same period.

Consulting service is offered to prospectors, miners, and Territorial and Federal agencies by engineers of the Department. The service is offered to those who cannot afford technical assistance and is therefore non-competitive to the practice of local professional engineers. Many requests for this type of service were received during the biennium, and many properties were examined and reports and maps made.

Coilections of classified rocks and minerals, and rocks and minerals of Alaskan origin, are maintained at each field office for reference by the prospector and miner. As new minerals advance to economic importance, with changing conditions of demand and use, the Alaskan prospector has ready reference to these collections for study.

A close cooperative exchange of information was carried out between the Department of Mines and the Atomic Energy Commission on radioactive samples originating in Alaska. Radiorctivity detectors of latest types, and standards for quantitative determinations, were installed at all offices. The headquarter office at Juneau recently installed a completely automatic detector of latest design for delicate determination of low-grade samples.

\section{Field Investigations}

Field examinations and technical assistance were given by the Department staff to those requesting such services. Proper ties were examined in the following localities during the biennium: Hyder, Ketchikan, Petersburg, Skagway, Haines, Valdez, McCarthy, Chisana, White River, Willow Creek, Matanuska Valley, Kenai Peninsula, Talkeetna, Nenana, Fairbanks, Livengood, Fortymile, Circle, Koyukuk, Ruby, Ophir, MeGrath, Flat, Bethel, Goodnews Bay, Nome, Kougarok, York, Sinuk River, Klery Creek and Shungnak in the Kobuk River region.

Placer occurrences under investigation were for the most part gold, but those containing platinum, tin and copper were also visited by field engineers. Investigations were conducted on lode deposits containing gold, silver, copper, lead, zinc, iron, bismuth and various non-metallic minerals for possible use in the manufacture of building materials. Several coal beds were investigated to determine quality and suitability for mining.

\section{Safety Inspections}

Safety inspections were made at properties visited by Department engineers. Unsafe conditions were brought to the attention of operating officials and in all cases rectified.

Monthly inspections of the coal mines in the Healy and Matanuska fields were made by the associate coal mining en gineer stationed at Anchorage. Smaller operations, such as the coal mine at Homer, were inspected at less frequent intervals as required. Due to the hazardous nature of coal mining, constant supervision of safety at the mines is absolutely essential if a low accident rate is to be maintained. The otherwise excellent safety record at the coal mines during the biennium was marred by the one surface fatality on the Alaska Railroad tracks, near the tipple of the Healy River Coal Corporation, in July 1950.

At the close of the biennium, both major underground coal producers-Evan Jones Coal Company in the Matanuska field, and Healy River Coal Corporation in the Healy field-had unionsponsored safety committees functioning, which were consulting and working with the Department and the managements of the two companies. This development should do much to keep the accident rate at a low level, as the men are thus encouraged to contribute to their own safety.

A considerable proportion of the time of the coal engineer was devoted to supervising control and extinguishment of the fire that broke into the workings of the Healy River Coal Corporation. The Commissioner of Mines also spent some time on this phase of the safety work.

\section{Assay and Field Offices}

The assay and field offices of the Department at Ketchikan, Anchorage, College and Nome performed the following analyses and identifications during the biennium, with similar determinations for the preceding biennium being listed for comparison:

\begin{tabular}{|c|c|c|c|c|}
\hline & 1947 & 1948 & 1949 & 1950 \\
\hline Golc & 1506 & 1016 & 949 & 1080 \\
\hline ical determinations .... & 428 & 373 & 258 & 292 \\
\hline Identifications & 437 & 679 & 585 & 506 \\
\hline
\end{tabular}

This service is free of charge to bona fide prospectors and miners and serves to encourage the search for minerals in the Territory. Due to the interest in radioactive minerals, a con- 
siderable number of uranium determinations were made, as well as numerous geiger counter tests and demonstrations. The latest radioactive detectors were installed and samples submitted to the laboratories from three areas in Alaska were found to be uranium-bearing. It is now evident that Alaska contains radioactive materials in geologic conditions that are similar to those in other uranium-bearing parts of the world, but much more intelligent prospecting is necessary before their economic importance will become known.

Steadily increasing base-metal prices resulted in increased interest in base and stragetic minerals, as indicated by a higher proportion of requests for determinations of this nature toward the end of the biennium.

The assay office at Ketehikan was completely renovated during the biennium to provide improved services to prospectors and miners in Southeast Alaska. Improvements were also made in facilities at the assay office that is located on the University campus at College.

A minor part of the time of the assayer-engineer who is stationed at Nome was devoted to mineral identification and a few gold assays. His principal duties were field examinations in northwestern Alaska, in the course of which technical assistance was given with mining and development problems, safety examinations were conducted at operating mines, sampling and mapping accomplished, and reports prepared. The assayerengineer stationed at College also did some field work of a similar nature.

\section{THE MINING INDUSTRY}

During the biennium of 1949-50, Alaskan mineral production increased from the post-war slump of 1948. The production of gold increased by about 50,000 ounces in 1950 over the preceding year. There was a flurry of gold speculation in 1949 due to a rumored increase in the price of gold, but this was suppressed liy the U.S. Treasury announcement in the fall of that year that there would be no increase. Production of coal decreased from 435,000 tons in 1949 to a little over 400,000 in 1950 due to one of the defense establishments converting to oil. The mining of platinum metals continued at a high rate, with an increase in production reported for 1950 over the previous year. Adverse economic conditions still plagued the industry, and the high wages offered on defense projects made it extremely difficult for mining companies to compete in the labor market.
The surprising increase in the production of gold was not indicative of true conditions, as fewer men and companies were engaged in this phase of the industry. The increase was due in part to greater efficiency in labor and equipment that has made it possible for the industry to survive in any degree. The gold-mining industry is now caught between the rising costs of labor, material and supplies, and the established Treasury price of $\$ 35$ per fine ounce for the product.

A deplorable aspect of this condition is that the best parts of pay limits are being mined in order to stay in business, and marginal areas are left behind and probably will never be worked. Stripping and thawing were neglected by many operators who were faced with the difficulty of holding crews to operate dredges and other heavy equipment, and lack of such preparatory work will eventually result in delays and in some instances closing down. Small operators have improved their efficiency to a high degree by replacing men with machines and adopting latest mining methods utilizing sluice plates, automatic giants, washing plants, and systems of great versatility.

Some attempt at a comeback in lode mining was made during the biennium when two of Alaska's former important gold producers, the Alaska-Pacific Consolidated in the Willow Creek district, and the Hirst-Chichagof in the Chichagof district of southeastern Alaska, commenced operations. However, on the whole, lode activity and production from that source were slight. The mining industry would undoubtedly have been able to increase substantially the present critically short supply of ?ase metals, had conditions been such that gold-lode mines could continue to operate, as one or more of the base metals are usually recovered as by-products to such mining. For instance, the Alaska Juneau Mine produced about 1,000 tons of lead annually while in normal operation. The ore at this mine also contains zinc that could probably be recovered if an incentive were offered.

During 1950 the Territorial Department of Mines received permission from the U.S. Atomic Energy Commission to release information in its files, and the announcement that there were three and possibly more areas of radioactivity in Alaska, created considerable interest in these minerals. Uraninite has been recognized in samples submitted to the Territorial Assay Offices from the Hyder district in southeastern Alaska, from Medfra in the Kuskokwim district, and from the Haycock area on Seward Peninsula. 
In southeastern Alaska uranium minerals have been identified in the dikes of the Hyder area, which are genetically related to the igneous rocks of the Coast Range Batholith. A great deal of prospecting is necessary here before the true economic value of the discovery can be estimated. In the Kuskokwim district near Medfra, uranium minerals have been identified in a lode adjacent to an area of intrusive rocks. The importance of this occurrence is yet to be determined. North of Haycock on the Seward Peninsula, placer concentrates have been found to contain uranium minerals. For some time uranium-bearing cuncentrates have been recovered in the sluice boxes of the placer ininers in that area, indicating a probable lode source nearby. Radioactive minerals in significant quantity are also known to occur at other localities in the Territory.

From what is now known, it is certain that Alaska contains uranium in geologic setting similar to that elsewhere in the world in which such minerals occur. Information on the geology of radioactive minerals, and a recapitulation of the work done by the Department on such materials, will be published in ramphlet form in the near future. The Department of Mines and the Atomic Energy Commission have been working in close cooperation in exchanging information, and in an effort to interest as many prospectors and mining companies as possible in the exploration for radioactive minerals.

The search for and interest in radioactive ores should increase with the stimulation of the Atomic Energy Commission bonus offer of $\$ 10,000$ for the discovery and production of the first 20 tons of acceptable ore, in addition to the purchase of this material at a guaranteed price.

Rising prices for the base metals-copper, lead, zinc, and tin, and the strategic and critical minerals-antimony, mercury, and tungsten, led to increased interest in the production of these minerals the latter part of the biennium.

Ammual assessment requirements on mining claims held by location again became effective in 1950, although date for completion of such work was advanced from July 1 to October 1. These requirements had been suspended from year to year during and after the war period, from July 1, 1941 through the assessment year ended July 1, 1949.

Prospectors and small mine operators were somewhat periurbed the latter part of 1950 by publicity given to rumor that from time to time has accused the Department of the Interior of plans toward amending the mining laws to provide for leasing of all mineral lands.

\section{Future and Needs of the Industry}

The future for the mining industry in the Territory depends upon several factors. As long as there is no change in the U. S. Treasury price of gold or change of policy to permit selling gold in the open markets of the world, there cannot be any improvement in the gold mining industry under present adverse conditions.

Coal mining, second only to gold in importance to the mining industry, where costs are passed to the consumer, is at present in good condition, and the demand for coal will increase with the completion of steam plants now under construction or planned.

Base metals, and minerals that are classed as strategic and critical, offer the greatest challenge to the mining industry of Alaska today. With exceptionally high metal prices, efforts should be made to prospect and develop the known occurrences of these minerals. The Territorial and the Federal governments should help the industry by exploration and venture capital where necessary.

The Federal government, through its Defense Minerals Administration, created in 1950 to expand the base and critical metal industry during the period of emergency, should commence a mineral buying program in the Territory. There are in Alaska many small deposits of antimony, mercury, tungsten, tin, etc. where a few tons of easily minable ore could be extracted; but since there is at present no market, no effort is made to mine such deposits. A buying program along the lines worked out by Metals Reserve Company during World War II, and carried out by the Territorial Department of Mines, would tend to activate the base-metal mining industry.

Provisions of the Defense Minerals Act will have to be greatly liberalized to afford benefit to the small mine operator, who most needs assistance. Experience in the past with similar agencies proved that the complexities of rules and regulations governing grants of loans or other assistance were far beyond the average small mine operator to understand unless he also was a lawyer or accountant.

It can reasonably be expected that with radioactive minerals now known to occur in certain sections of the Territory, pros pecting for this type of mineral will accelerate. 
There is but little official information available on the results of the Navy's oil drilling project on Naval Petroleum Reserve No. 4 north of the Brooks Range. During 1949 and 1950 unconfirmed reports indicated gas had been obtained in the wells in sufficient quantity for camp use and that the outtook was optimistic.

Interest in the manufacture of building materials continued, and future plans are expected to include development of the ljght-weight, bloated, haydite-type materials.

Considerable interest developed during the biennium in iron we deposits of southeast Alaska. Claims were staked on two of the more promising occurrences and investigations were conthcted by private engineer's for steel companies and representatives of Japanese purchasing agencies. The immediate demand is for shipping ore, although consideration is also being turned toward producing a marketable iron concentrate.

Plans wele announced at the end of the biennium for test well drilling of a large acreage, said by promoters of the project to be under lease from the Department of the Interior in the Katalla field. from which has come the only commercial production of petroleum in Alaska.

\section{Placer Mining}

Placer mining remains the mainstay of the Alaskan mining industry. Production declined in 1949 and increased to about its 1948 level in 1950 . There were 1,838 men employed in 264 piacer operations in 1949 and 1,722 men in 265 operations in 1950. In 1949 placer gold production was 221,089 ounces and in 1950 about 268,700 ounces. The increased production was due in part to the reopening of one of the formerly idle $U$. $S$ Smelting. Refining and Mining Company dredges in the Nome district and also to increased efficiency of the smaller operations.

Because of the government defense projects, which pay much higher wages than the mining operators can afford, efficient labor and equipment operators became more difficult to obtain. The supply of labor available to the mining industry in i949 was fair and in 1950 it was good until about the middle of $j u l_{y}$ when a large number of construction projects were started and the men began leaving the mining camps for the betterpaid employment. Under the present national emergency, with lefense projects again starting, crews for the mining industry will be difficult to obtain, and mines will have to operate on a restricted basis. Accompanying difficulties that will cause cur tailment will be increased prices and scarcity of equipment and supplies.
The larger dredging concerns have been able to continue operations in spite of rising costs by holding crews sufficient to operate the dredges and by neglecting stripping and thawing. Neglect of this preparatory work will, of course, eventually close down the operations that have only limited areas prepared.

Tho smaller placer operators improved efficiency further by replacing older methods and large crews with bulldozers, draglines, washing plants, sluice plates, automatic giants, and other modernized aids to mining. The buldozer-dragline combination has been used for years and in addition, washing plants, which ure actually mobile dryland washers, have recently become increasingly popular. The washing plant is especially useful when

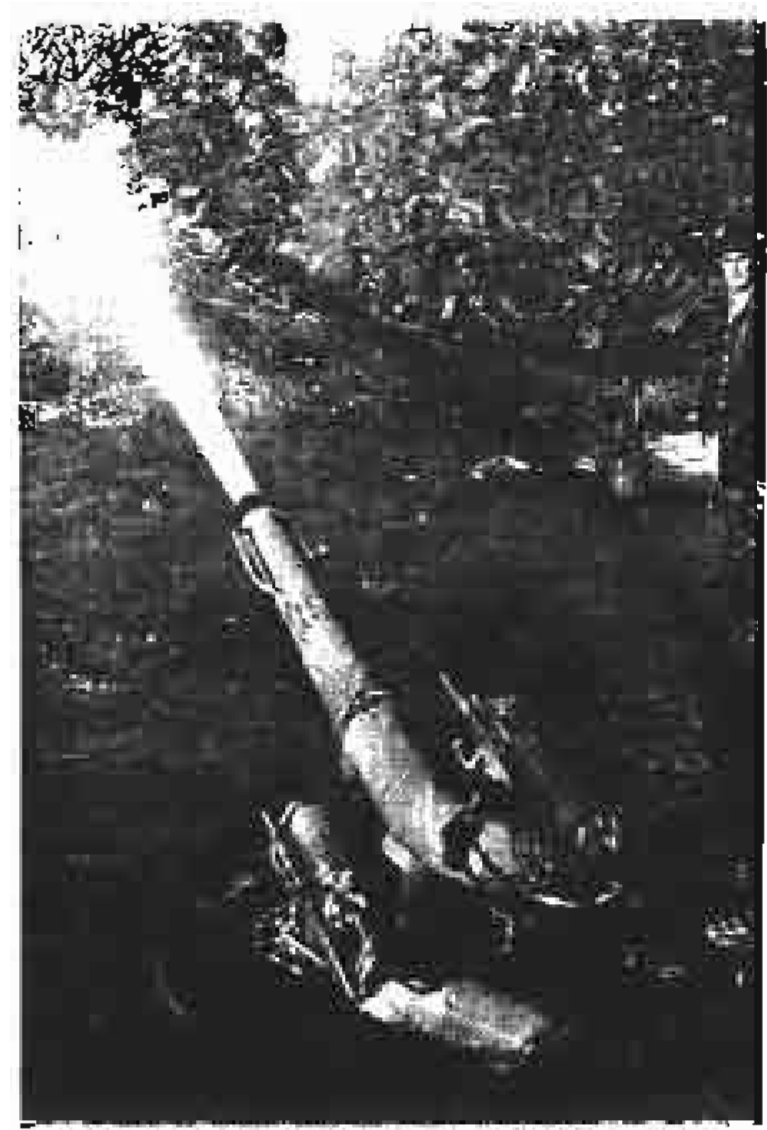

welugiant developed by John Miscovieh, stacking tatings at lower end of sluices Tony Zimmerman aperation on Independence Creek, Circle district. of gravel are available for dredging, and operations must be moved from place to place as pay gravels become exhausted.

I) crelopment of the "Intelligiant" opens to the placel. miner a cheap method of moving gravel and muck where hydraulic water is plentiful. Water - activated cylinders automatically control the horjzontal and vertical direction, as well as the speed and width of the sweep of the hydraulie stream. This machine was first used during 1950 in the Circle district for antomaticaly stacking taijings. 
Another recent development is the sluice plate, which has met with success wherever it has been used. The system was first developed in the Fortymile district and has been adapted to other districts where the presence of clay is not a serious problem. This system utilizes a large dump box or plate at the ilead of the sluices, onto which the gravels are pushed from the side by bulldozers. Water is introduced from the upper end and carries the gravel off the plate through the sluice boxes. It has many advantages in that it eliminates the need for bedrock drains and giants and speeds moving and set-up.

Placer operators in the Yukon basin were during 1950 eriously hampered by lack of sluicing water because of an exceedingly dry season, in view of which increased production is surprising. Brief and general information on placer mining in the various districts follows, and all active mining operations in 1950 are listed at the back of the report.

\section{First Division:}

There were two placer operations active in the First Division during the biennium. One was the unique operation of Hayes and Whiteley of Juneau. This company recovered substantial quantities of gold from the mill tailings at Thane and Alaska Juneau Gold Mining Company. The operation consisted of hauling old mill tailings to a sluice box where concentrates were collected and later amalgamated to recover the gold content. At Windham Bay, Stanton Price sluiced some gold-bearing sravel at the mouth of Spruce Creek, using a bulldozer set-up.

Second Division:

Cape Nome District: During 1950 the Koyuk precinct was combined with the Cape Nome precinct and the operation of both are included here. Nine dredges were operating in this district during 1950, compared to eight in 1949, and one dredge was under construction. The largest producer during both years was the Nome Department of the U. S. Smelting, Refining and Mining Company, which had two boats in operation in 1949 and three in 1950 . Reopening of the third dredge by this company increased the placer production of the Territory considerably. There were twenty-one bulldozer-hydraulic operations active in 1950, four bulldozer-dragline, two straight hydraulic, and twelve prospecting and hand-mining operations.

Production of placer tin by a dragline and jig set-up on Buck Creek, east of York, continued during 1949 and 1950, and a substantial quantity of tin was recovered.
Fairhaven District: In the Fairhaven district, in the northeast section of Seward Peninsula, there were three dredges operating in both years of the biennium. The largest dredging operations were those of the Casa de Paga Gold Company, which had two dredges on Inmachuk River. There were four bulldozerhydraulic operations and three bulldozer-dragline combinations. Also, one straight hydraulic operation and one prospecting company were active.

Largest employer in the district was the Havenstrite Mining Company with four operations-a dredge on Mud Creek, tributary of Minnehaha Creek, and smaller operations on Bull Hill, Tump Creek and Camp 19 on Candle Creek

Noatak-Kobuk District: Mining operations continued at an even rate in this district during the two years of the biennium. In 1949 the Lammers Exploration Company dredge on Klery Creek was purchased by Helcolicon Mines, Inc., and the dredge was operated by the new owners in 1950. Helcolicon Mines also did considerable placer drilling on Salmon River during 1949 and 1950. There were also three hydraulic operations and one prospecting party active in the district.

St. Michael District: The dredge of the Ungalik Syndicate was idle in 1949, although the company crew conducted drilling during that year. No mining activity was reported in the district in 1950 .

Wade-Hampton District: Operations continued at a uniform rate in this district during the biennium. They were a bulldozerhydraulic, one bulldozer-dragline, one dragline, and one hand operation.

\section{Third Division:}

Chitina District: Placer activity in the Copper River area was almost at a standstill in 1949 and 1950. Only one each hydraulic operation, hand placer, and drift placer were active. A unique mechanized operation was that of C. J. McMahan on Albert Creek in the Nelchina area who used a carryall and bulldozer to move gravel to the sluice boxes.

Iliamna District: Harry Bowman mined by bulldozerhydraulic methods on Portage Creek near Lake Clark. A small amount of pumice was mined by placer methods on Augustine Island during 1949 by Alaska Katmalite Corporation of Anchorage, but the project was abandoned in 1950. In 1950 Stock and Grove mined some pumice on Geographic Bay off Shelikof Strait for building use in the Anchorage area. 
Moose Pass District: Placer mining in the area was practically dormant during the biennium, and only the drift mine of Jim O'Brien and Jim Dunsmuir on Surprise Creek near Skilak Lake was active.

Walkeetna District: This district was by far the most important placer gold producer in the third division, the dry-land washing plant of Collinsville Mines of Anchorage being the iargest. This operation, on Twin and Mills creeks in the Yentna area, is an outstanding example of the successful use of mobile washing equipment. Elsewhere in the Cache Creek-Peters Creek area there were three bulldozer-hydraulic, eleven hydraulic, and three hand operations.

\section{Furth Division:}

Bethel District: There were four operations active in this cistrict during 1949 and 1950. The largest operator, the New York-Alaska Gold Dredging Corp., mined with two dredges and a dragline during both years. In the spring of 1950 the $61 / 2$ foot dredge of the company was moved from the Tuluksak River to the junction of California and Rock Creeks and operated during the balance of the season. Elsewhere in the district, there were a bulldozer-hydraulic and a dragline-bulldozer operation active.

Chandalar District: This district had an increase in activity :nd during 1950 there were three operators-a bulldozer, a hand and a drift. A new mining operation, that of $R$. W. Sellars on big Creek, got under way in time for only one cleanup, but results indicated a good future might be expected for this operation.

Circle District: Fifteen companies were active in this area during 1950. Two dredges were operated each of the two years of the biennium-Berry Dredging Company operated on Mammoth Creek both years, and in 1949 Alluvial Golds, Inc. operated its boat on Woodchopper Creek, but closed it down in 1950. In 1950 the formerly idle boat of Gold Placers, Inc. on Coal Creek was put into operation. In addition to the dredge operations, there were two bulldozer-dragline, four bulldozer-hydraulic, four hydraulic and two hand operations. The district was hard hit in $I 950$ by one of the driest seasons on record. Ifew operators were able to sluice more than a few hours per day. The miners of this district are a progressive group and have, with few (xceptions, completely mechanized their plants.
Eagle District: 'Two bulldozer-hydraulic operations and two hydraulic operations were active in this district both years of the biennium.

Fairbanks District: Thirteen mining companies, operating seventeen placer units, were active during 1950 in this district. The district was by far the most important producer of placer gold in the Territory. Of the total number of operations, six were dredges, two were bulldozer-dragline, five were bulldozerhydraulic, one hydraulic, two were stripping, and one was hand mining. U. S. Smelting, Refining and Mining Company operated five of its eight dredges in 1949 and 1950. The Goldstream dredge was moved to Fairbanks Creek during the winter of 1949-50 and operated at the new location during 1950. This company also had stripping operations at Cripple, Gold Hill, sheep Creek, Engineer Creek, Dome and Fairbanks Creeks; and thawing operations at Cripple Creek, Engineer Creek, Fairbanks Creek and Chatanika. Operations of the company were closed down in May of 1950 for three weeks by a strike of the local miners union. In the Salcha district the Brinker-Johnson Mining Comyany continued dredging during 1949 and 1950 with very good lesults. An interesting development in the old Tenderfoot camp south of Fairbanks during 1950 attracted attention when G. B. Martin started a bulldozer operation on a residual placer at the ridge between the head of Bush Creek and Hinkley Gulch. The :mall operators had a very difficult time during 1950 because of the dry season.

Fortymile District: Thirteen placer operations were in progress during 1949 and twelve in 1950. Of this total, one was dragline-bulldozer, eight were bulldozer, two were hydraulic, and one was hand sniping. The Yukon Placer Mining Company was the largest producer and had three operations in 1949. In 1950 this company moved one operation to the Eagle district and another into Canada. A very dry season caused difficulties in 1950 .

Fort Gibbon-Tanana District: Three widely separated operations were active in this district in 1950. Two were bulldozer operations, and the largest producer, Strandberg and Sons on Utopia Creek, tributary of Indian River, used a dry-land washing plant and draglines. 


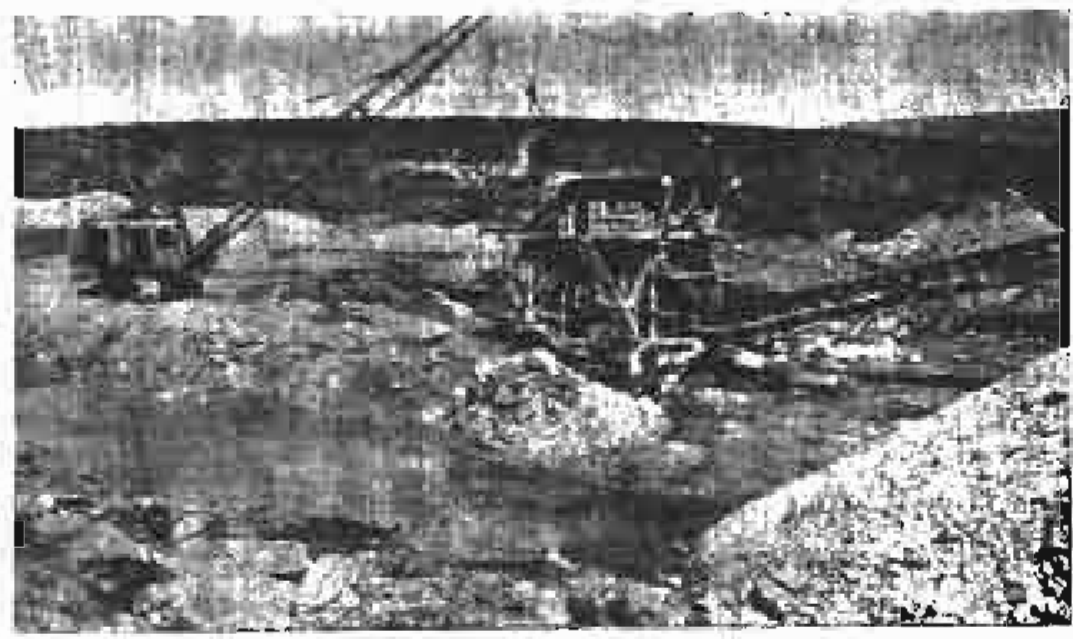

Strapdiber \& Sons washing plagt on tutopja Creek. Fort Gibbon Precinct - Tanans district

Goodnews Bay District: The Goodnews Bay Mining Company operated its platinum dredge on Salmon River during the biennium and produced a large amount of crude platinum. The recovery system of the dredge was improved during the summer of 1950 by all extension on the trommel screen and the installation of a high-pressure screen washing system. The company also mined with a dragline-bulldozer set-up, which operated for the first time in 1950 on a three-shift basis.

Hot Springs District: Mining in this district proceeded at about the same rate as in the prevfous biennium, and ter companies were active during 1950 . There were one draglinebulldozer, six bulldozer and bulldozer-hydraulic and three drift mines active.

Iditarod Districh Otter Precinct: A total of ten companies were active in this district in 1950. These were one dredge, four (iragline-bulldozer, two bulldozer-hydraulic and three hydraulic sperations. The dredge of the North American Gold Dredging Company operated during both years of the bientium and was the largest producer and employer in the area.

Innoko Precinct, Ophir District: This was an active mining district during the biennium. Three dredges, seven draglinebolldozer, and three bulldozer-hydraulic operators were mining in 1950 and had good seasons. The Innoko Dredging Company completed reconstruction of the Ganes Creek dredge during 1949 fnd operated it in 1950. Strandberg and Sons also started their formerly idle dredge on Candle Creek during 1950. Another new jperation during 1950 was that of Richard and John Fullerton, who took over ground on Colorado Creek that was prepared in 3949 by the Goodnews Bay Mining Company.

Kantishna District, Fairbanks Precinct: Only one bulldozer operation was active in this area during the biennium.

Koyukuk District: A total of nineteen operations were active in this district during 1950 . They were one draglinedozer, six bulldozer, three hydraulic, eight hand operations and one drift. Myrtle Creek Mining Company, operating by draglinebulldozer methods, was the largest producer in both 1949 and 1950 .

Kuskokwim District (Kuskokwim Precinet): Only two operators were active in this district during the biennium and both were dragline-bulldozer combinations.

Nenana District: Seven separate placer operators were active in this area during 1950. Two were bulldozer-hydraulic, one was hydraulic, and four were hand mining. All operations in the area have small crews.

Rampart District: There was an increase of operations in the district from six in 1949 to eight in 1950 . Of these, one was a dragline-bulldozer, five were bulldozer-hydraulic and two were hand operations. Largest operator in the district was the Little Minook Mining Company. using bulldozer, bedrock boxes a!ld a dragline on Little Minook Creek.

Ruby District, Nalato Precinct: Three operators using dragline set-ups and two operations using bulldozers were active in the area in 1950. Largest operation was that of $P$. Miscovich and Sons using a dragline and bulldozer on Flat and Timber Creeks.

Tolovana District, Fairbanks Precinet: Seven companies were active in this district during 1950. Livengood Placers, Inc. on Livengood Creek was operated in 1950 under the parent company name, Callahan Zinc-Lead Company, Inc., and work preparatory to dredging was continued with the largest crew in Llie area. Olive Creek Mines, operated by Parker and Heflinger, was the largest producer of placer gold in the district both years of the biennium. Elsewhere in the district there were one bulldozer, two hydraulic plants, one prospecting venture, and one maintenance operation. 


\section{Coal Mining}

During the biennium a new all-time high in coal production was reached with a total of 840,000 tons. The 1949 production was 435,000 tons, but the 1950 production dropped silghtly to 405,000 tons due to one of the defense establishments converting. temporarily to oil. Although Evan Jones Coal Company in the Matanuska field, and Healy River Coal Corporation and Usibelli Coal Mine, Ine. in the Healy field contributed most of the proItrction, the following list of coal mining operations indicates ill the mines that were at any time active during the biennium

\section{(Matanajka Field) (Bltaminoes)}

$\begin{array}{ll}\text { Evan Jones Coal Company (noderground) } & \text { - Operated } 1949 \text { and } 1950 \\ \text { Buffalo Conl Company (underground) } & \text { Reopened } 1950 \\ \text { Knob Creek Coal Company (underground) } & \text { Closed down in 1980 } \\ \text { Houston Conl Company (strip) } & \text { Operated 1948 and } 1950\end{array}$

\section{Fouston Conl Company (strip) $\quad$ Operated 1949 and 1950}

\section{(Homer Field) (Sab-bitrminons}

Homer Coal Corp. (undereround atrip) Expanded exploration 1950

\section{(Healy Field) (Sub-bitominons)}

Healy River Coal Corp. (underground \& strip) Operated 1949 and 1950

Dlamond Cosal Company (strip)

Cripple CTeel Cosl Company (stelp)

closed down exrly in 1849

Usibelil Coal Mine, Inc (strip)

Began operatlons fall 1950

Operated 1949 and 1950

\section{(Point Barrow Field) (Sub-bltominons)}

Meade Rtver coal Mine (A.R.S.)

\section{Mfatanuska Field:}

Important improvements were made at the mine of the Wvan Jones Coal Company at Jonesville during the biennium. $A$ new heavy-media coal cleaning plant of latest design, with suriace bins. crushers, and complete equipment including a waber using if Chance cone, was constructed. This new principle of coal-rock separation, using a magnetite mixture for heavi nedix, js the latest modern equipment, and should go far towurd improving the quality of Fvan Jones coal. A laboratory was established in connertion with the new washer for the determination and control of ash content in the coal. Conditions in the underground operations were also notably improved, and nechanjzed equipment, including coa] cutters and mechanical loaders, was on order and en route at the end of 1950 .

In the fall of 1949 the Alaska Road Commission constructed il new highway from Sutton on the Glenn Higbway to the proverty. This highway, following the easy grade of the Alaska hailroad, is an important improvement over the old highway which followed the ridges to the west. Three new entries on

coal found by drilling, about a mile west of the Jonesville tipple, were attempted. A complete surface set-up was made, with bunkers, hoists, compressors and power lines, but because of unexpected faulting, the relationshlpg were not worked ont, and the work was abandoned.

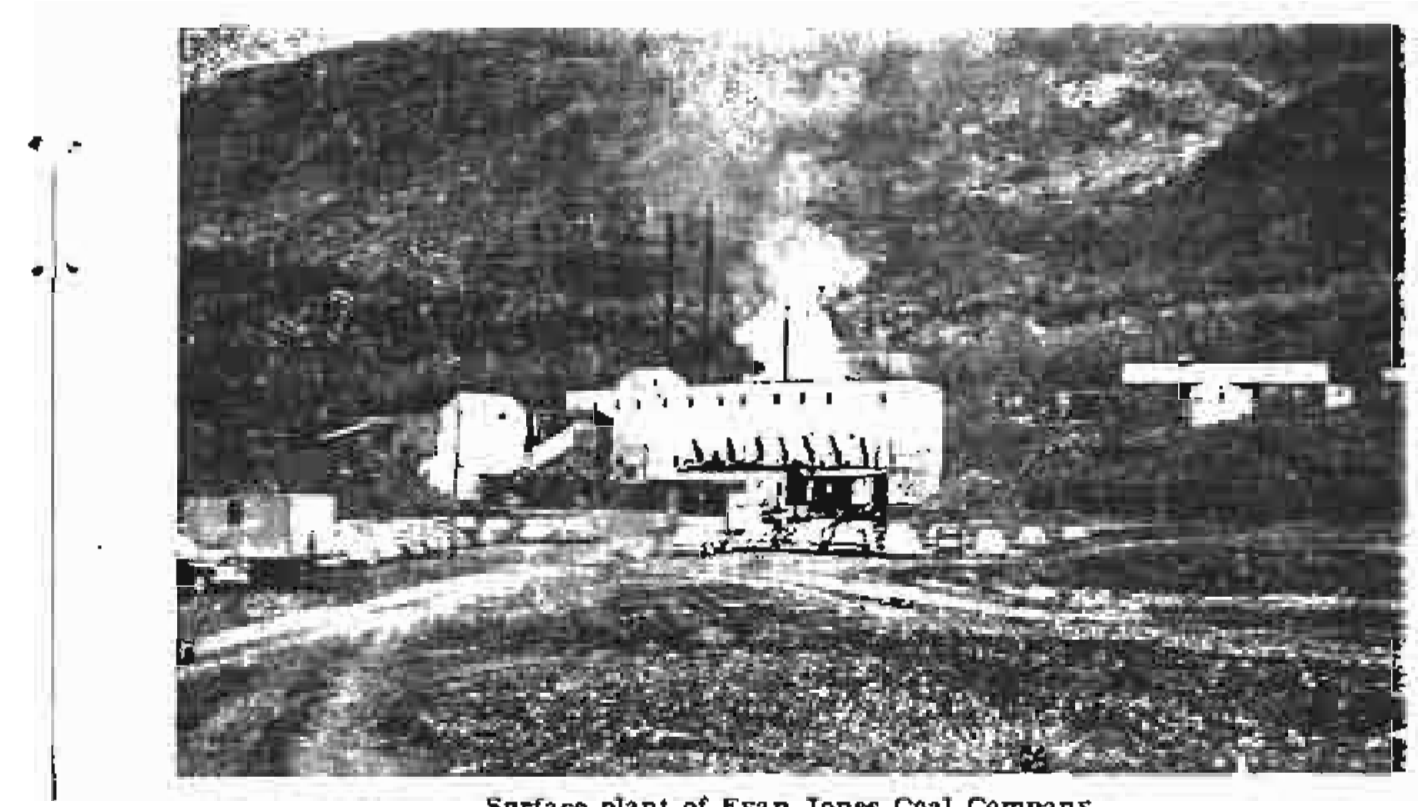

Surface plant of Evan Jones Coal Company.

The Buffalo cual mine on Moose Creek was opened by the Norris brothers during the spring of 1950, after it had been ciosed for a number of years, and rehabilitation of the surface Hlant and pumping of the shaft were started. A 150-K.V.A. steam turbine was obtained and installed for electric power, and jreparations were made to start a new slope on Ded No. 1.

Small-scale operations were continued at the Premier mine of the Alaska Matanuska Coal Company, located on Moose Creek at the northwesterly end of Wishbone Hill. A small production was obtained from near-surface remnants above water level on several of the coal seams in the flooded slope-workings of the old mine, which in the past has yielded a large tonnage of exreptionglly higl-grade bituminous coal. Also during 1950, surface prospecting was carried out by bulldozer-trenching in an 
effort to work out some of the complex geology east of the property and in an attempt to locate the coal beds between the Premier and old Baxter mine.

At the Knob Creek mine east of the Jonesville mine an unexpected fault in the workings forced abandonment of attempts to open a mine, and the property became idle early in the spring of 1950.

In an effort to expand the bituminous coal reserves of the Matanuska field, the Department of the Interior was conducting during the biennium, under the direction of the U. S. Bureau of Mines, a diamond-drilling program in the area west of the fonesville mine. Additional drilling is planned in the same area for the open season of 1951 .

At Houston on the Alaska Railroad, the Houston Coal Company continued stripping operations on flat-lying seams, and during 1950 contributed to the rail belt and military coal supply. A washer was completed on a spur of the Alaska Railroad in 1949. The operation consists of stripping off the shallow overburden by bulldozers, blasting the coal, and loading into trucks with power shovels. The trucks haul the coal to the washer, located about half a mile to the north on the Alaska Railroad spur. Future development plans include a drilling program and «n increased production schedule.

\section{Komer Field:}

Small-scale coal mining operations were continued during the biennium at the property of the Homer Coal Corporation, located at Homer on lower Kenai Peninsula. Duxing 1950 a complete engineering study, including the drilling of 23 holes, blocked out a considerable quantity of coal, and a little nearsurface strip mining was done. The opening of the HomerSeward highway during the summer of 1950 should result in an increased market for this coal on Kenai Peninsula.

\section{loint Barrow Field:}

Coal for use by the Eskimo inhabitants at Barrow, on the Arctic Coast, continued to be mined at the rate of about 1,000 tons per year at the Meade River mine, which was opened in 1943 by the Alaska Native Service at a point on Meade River about 70 miles south of Point Barrow. This small mine has served to alleviate a very serious fuel problem for the inlabitants of the Point Barrow region.

\section{Healy Field:}

Strip mining operations have become an important source of coal from this field since the war period, and their importance is shown by the fact that all of the operations in the area, with the exception of those of Healy River Coal Corporation, are stripping, exclusively, and even that company produces a substantial tonnage from its surface pits. In 1949 and 1950 a total of 480,000 tons, valued at about $\$ 3,279,000$ was produced in the Healy field, of which 210,000 tons was stripped.

The Diamond Coal Company, operating the Norris-Parris leasehold four miles southwest of Healy, opened a new strip pit in 1948, approximately one mile west of the main pit. Due to the extremely faulted nature of the ground, extraction of clean marketable coal became very difficult, and efforts to mine were finally abandoned in 1949. The property, which is well equipped with tipple, machine shop, garage, warehouse, and camp on the Healy railroad siding, remained idle during 1950 .

The mine of the Healy River Coal Corporation at Suntrana continued underground mining at about the same rate as in the previous biennium. This mine has been operating for 30 years, producing the bulk of the coal consumed in the Tanana Valley during that time. A characteristic of the coal in the Healy subbituminous field is the spontaneous combustible nature of the coal, which condition requires unusual vigilance and skill in mining. Gob fires are easily started and are extremely difficult to extingumish. In September 1950 an underground fire of long standing broke through its seals, and a gob fire developed by spontaneous combustion, after the shutdown caused by the strike at the Fairbanks workings of the U. S. Smelting, Refining and Mining Company, which company is a large user of Healy River coal in its power plant. This fire caused a great deal of trouble and delay. Due to the vigilance and efforts of the Department of Mines coal mining engineer, no one was injured, the old fire was again sealed off, and the new fire was extinguished.

Notable improvements have been made in the mining system used on beds Nos. 2 and 3 of the Healy River Coal Corporation underground operation. The credit for success of these new mining systems goes to the mine staff which has long worked on the problem of efficient extraction of the thick, pitching seams. An important improvement was made in the underground liaulage system in the fall of 1950 , with completion of a sand haulage tunnel in the footwall of Bed No. 1 at a distance from the bed. This area, close to the portal, has been difficult and expensive to maintain, due to the heaving character of the footwall. At the end of the biennium, equipment, including 
Cripple Creek Coal Company, on the permit of A. Ben

mechanical coal cutters and loaders, were on order and should do much to improve efficiency and lower costs of this operation. Buring the biennium, a strip pit was opened on Bed No. 1 on jroperty adjacent to the Usibelli leasehold, and production from this new pit started in September 1950. A modern, $24 \times 72$-foot office building was finished during the biennium and added much to the comfort and efficiency of the staff.

Usibelli Coal Mine, Inc. continued stripping and mining cluring the biennium on Bed No. 1 , which is approximately 45 teet thick. A record tonnage was mined to supply an army confact late in 1949 and early in 1950. The gravel overburden is stripped with hydraulic giants and the sandstone hangwall is blasted then removed by the giants. Coal is blasted and loaded by power shovel on trucks for the 3-mile haul to the tipple on the Alaska Railroad tracks near Suntrana. Due to limited contracts, mining was somewhat curtailed the latter part of 1950; however, stripping was continued and this mine has ample reserses ready for mining. During 1950, a new and commodions shop with an area of 7,000 square feet, a large and modern dry "oom with radiant heating, and four well-constructed and comfortable family bungalows were built. With the tipple and other wxisting improvements, and the new construction, this camp now is one of the best-equipped in the Territory. The surface plant is already well prepared for the time when plang for underground mining are carried out.

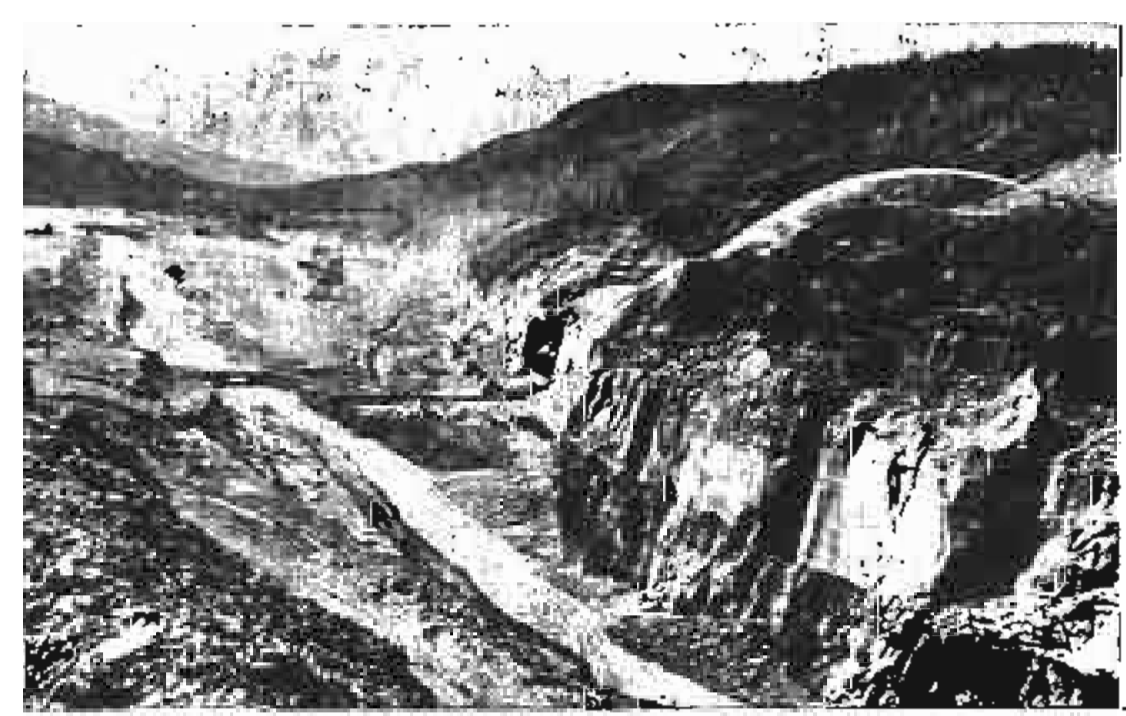

Strippine operbarden on Bed No. 1 by hydranllo Etant-Osheill Coal Company, Healy Purer, Healy coal fletd.
Shallit adjacent to the Usibelli Coal Mine, Inc property, commenced operations in the Healy River district in 1950. Produciion for an army contract began in November from beds exposed in Cripple Creek, a tributary of Healy River. The overburden on the principal exposure, which is 45 feet in thickness, and which is believed to be an extension of Healy River Series Bed No. 1, was stripped by bulldozers. The coal is blasted and loaded on trucks by power shovels, and hauled six miles to a loading ramp kelow Suntrana on the Alaska Rajlroad. A camp at the mining site, and six miles of road on the north side of the Healy River valley, were constructed in August and September. Overburden was stripped during the same period and sufficient coal to fill the army contract was exposed for extraction. The rapidity with which this previously undeveloped area was brought into production is an outstanding example of good planning and management.

\section{Future and Needs of the Coal Mining Industry}

In view of the present trend toward mechanization of underground operations, it can reasonably be expected that production per man will be increased; however, the reverse may be expected it the strip mines, as their stripping limits are reached. Due to steep pitch, and location of most Alaskan coals, reserves of coal that may be stripped are limited, and are being depleted at a rapid rate. The solution to the problem of a long-range supply of coal is underground operation.

A substantial increase in the demand for coal is expected, ws there are some $32,000 \mathrm{Kw}$. in steam power plants now being bailt in the railroad belt. This figure includes about $12,000 \mathrm{Kw}$. in the Tanana Valley and $20,000 \mathrm{Kw}$. in the Anchorage area. It can, therefore, be predicted that the yeurly consumption of coal in Alaska will rise to 500,000 tons within the coming bientium,

This presents a challenge to the coal industry, especially to the operators in the Matanuska field where oil is competitive. Coal producers will have to increase output if markets are not to be allowed to turn to oil because of their inability to meet the demand for fuel.

Those Alaska communities such as Anchorage and Seward. which are so situated that they could economically utilize waste steam for hesting, should study the example of Fairbanks. The Fairbanks utility system is presently constructing a power plant. 
for the generation of electric energy, which will utilize the low pressure waste steam for heating sections of the city. This system has proven highly successful in the past in Fairbanks and elsewhere throughout the world.

There is a distinct need for a procurement policy, and clear statement of anticipated annual coal consumption and stockpile requirements by the military establishments. As the military is the largest consumer of coal in the Territory, much confusion exists until annual awards are made, and operators are forced to close their mines at times until awards are made. Awarding of semiannual contracts on smaller lots might prevent operators iailing to gain annual contracts from being closed down for long periods.

In view of the increasing importance of the coal industry, and the substantial amounts of coal consumed yearly, there is in urgent need for a coal-analysis laboratory in the Territory. At the present time there are no such facilities, and coal must be sent to the U. S. Bureau of Mines laboratory at Pittsburgh, I'ennsylvania for analysis, thereby consuming so much time that Alaskan coals are rarely tested.

A reactivated first-aid and mine-rescue program is badly needed in the Territory at this time. Practically no trained men are available at present in case of disaster, and there are no organized safety teams to conduct rescues. The Safety Division of the U. S. Bureau of Mines in Alaska should be revived to conduct this important work. It would greatly aid the engineers of the Department of Mines, and the safety committees or safety engineers of the mining companies in maintaining a low accident rate. A continuing program of safety training to establish fully trained and equipped mine rescue teams immediately available in case of disaster is an urgent requirement of the coal mining industry.

\section{Lode Mining}

Lode mining continued to decline during the biennium, as indicated by tables III and IV in following sections of this report, in spite of the fact that two of the formerly important producers of lode gold began operations on a reduced scale. Present conditions certainly are not favorable to early return of lode-gold mining to its former important position in the mining iildustry as a producer and employer. More hopeful for the immediate future in lode mining seems to be the possibility of developing base and critical metallic minerals, as well as nonmetallic minerals for use in the building industry.
During the biennium of 1949-1950 only one base metal proberty was operated in Southeast Alaska. This mine, the Riverside, a leald-tungsten property near Hyder employing.about 32 men, has been able to operate only because it was able to hire low-cost Canadian labor and ship over Canadian steamship lines.

In the Ketchikan district on Prince of Wales Island, Wendell

Dawson continued to mine and mill on his gold lode near Hollis. Mr. Dawson has consistently operated and shipped concentrates to the smelter since the war.

The Lake Bay Mining Company on Prince of Wales Island was active for a short time during 1950, as also was Elmer Johnson and associates at the Londevan property on George Inlet near Ketchikan.

Robert Novatney of Juneau was actively developing a goldJode prospect on Helm Bay near Ketchikan during the biennium.

The Tillicum Mining Company of Ketchikan did a small amount of tunnel work on the Dora Lake lead-zinc prosuect on Prince of Wales Island. The work was under the supervision of (ieorge Roberts.

In the Wrangell district, L. C. Berg of Sitka had a diamonddrill crew at his lead-zinc property in Berg Basin both open seasons of the biennium.

There was some interest in the iron deposits of Southcast Alaska during the biennium. W. S. Pekovich of Juneau staked an iron deposit at Snettisham, and obtained samples for metaliargical tests in the summer of 1950. Negotiations were under way at the end of the biennium for outside capital to develop this property. The Alaska Iron Company of Haines was engagod in staking and developing a magnetite-hornblende deposit during the biennium near Klukwan, 24 miles northwest of Hain: s. The froperty consists of placer claims on the alluvial lan p.raneing tise ridge to the northeast of the village of Klukwan, and locle ciaims on a mineralized zone on the mountainside above the placer. Apparently, there is a jarge tonnage of mineralized material on this property, but only extensive testing will determine bine feasibility of producing marketable iron ore or concen.rates.

Herman Kloss and Jack Davis continued development work auring the biennium on their promising gold-antimony prospect a! Sunset Cove near Windham Bay.

The Alaska Juneau Gold Mining Company maintained a crew of 31 men during the biennium, which was engaged for the most part on maintenance of power plants and lines, mill and other equipment. 
In the Chichagof district, Slocum Arm Mining Company maintained at its property on Slocum Arm a small crew that was engaged during the biennium on assessment work and some surveying and mapping. Ole Twedt worked alone at developing his gold lode on Klag Bay during 1949 and 1950.

The operation receiving most attention during 1950 was the reopening of the well-known Hirst-Chichagof mine at Kimshan Cove. This mine has been a substantial gold producer in the past, and was closed by the Government L-208 order during the last war. The rehabilitation program was in charge of Paul $M$. Sorensen, who was also manager for the company at the time the mine was closed, and for several years prior to that. He had a crew of six former employees of the company.

Aiso of interest in the Chichagof area, was the operation of Ilayes and Whiteley Enterprises of Juneau at the Chichagof mine. This company had a crew of seven engaged during 1950 in remilling tailings, utilizing a dragline lift to the elevator, thence to the mill. This mine, fur many years prior to its closing arly in the last war period, was one of the principal lode-gold producers in the Territory.

In the Glacier Bay area, Leroy Mining Company operated curing both years of the biennium with a small crew. Concenirate shipments were made to the Tacoma Smelter. Charles Parker was prospecting a lead-silver-copper showing near Excusion Inlet in 1950.

Mines of the third division in the Willow Creek district were the principal producers of lode gold in the Territory during the biennium. This production, although small, was on the increase. The Alaska Pacific Consolidated Mining Company reopened its independence mine late in the 1949 season. The operation commenced with the inauguration of a leasing system for the extraction of ore-the first attempt of the kind in Alaska-although a similar system has been successfully used for a number of years in certain mining districts of the western states. Mining and milling operations continued in 1950 on a highly efficient one-shift basis. However, late in 1950, the operation closed down for what was described as an indefinite period.

The Fern mine was operated on Archangel Creek during 1949 and 1950, and some production was reported in both years. The company was reorganized during the fall of 1950 .

Snowbird Mining Company, Inc. continued its development program, and construction completed during the biennium in included a mill of modern design, hydro-diesel power plant, and a complete camp. Underground development also continued but there was no production.

Others active in the Willow Creek area included Jack Lane, who was developing the Glacier claims on upper Archangel Creek and some development work on the Webfoot gold lode by $W$. Conroy, also in the Archangel Creek area. Frank O'Neil and Ward Sroufe made an exceedingly rich strike on Craigie Creek inci spent the summer of 1950 developing the lode and preparing to mill the ore in one of the mills of the district.

At Girdwood, Joe Danich did some development work and improved the mill on the old Jewel and Monarch properties during the biennium.

On Kenai Peninsula, the Falls Creek Mining Company, near Moose Pass, mined and operated its mill during 1949 but closed down in 1950. On Palmer Creek near Hope, Iver Nearhouse did some development work on the Gold Mint claims.

In the Fairbanks district of the fourth division during the biennium, Vern Jokela and Charles Lazeration worked the Greenback claims of the old Robinson property on Pedro Dome near the head of Eldorado Creek, milling their ore at the Cleary Hil Mines Company mill on Cleary Creek. Near this operation toward the head of Cleary Creek, at the Tolovana mine, Howard Spark mined antimony and a little gold during 1949. This property was in litigation and was closed in 1950 . E. L. Kaye operated the Sanford property in the Ester Dome area during 1949, but it was idle in 1950 . Also in the same area, Earl Beistline operated the O. M. Grant property on Happy Creek during 1949. Both Beistline and Kaye milled their ore at the mill near the head of: Ready Bullion Creek on Ester Dome. Doug Jackson and Ear Beistline operated the Cleary Hill mine during 1950 and milled their ore there. There was some prospecting activity at the Coffee lome by Walter Lindgren and associates. John Vuyovich during 1950 milled some ore from a lode on Ester Tome in the St. Paul mill on Eva Creek. The Four-A Mining Company pros pected a silver-lead occurrence near the head of Flume Creek.

A purchasing agency was set up in the Fairbanks area by Howard Sparks, who became a representative of Goldsmith Bros. Smelting and Refining Company of Chicago. Sparks was actively engaged in buying ore in this district. During 1950 he contracted to buy the 1948 production of the Sawtooth Mining Company near Rampart, and about 100 tons of high-grade antimony ore was on its way to Livengood from the property at the close 
of 1950 . No mining was reported by this company in 1949 and 1950, due to the low price of antimony, but active operations were planned for 1951 . The property is to be completely equipped and supplied.

Earl Pilgrim operated the Stampede antimony mine on Stampede Creek in the Kantishna district during 1949 and made some shipments, but only a little activity was reported at the property in 1950.

Elsewhere in the fourth division, Sam Gamblin and associates did some work in 1949 on his antimony claims on Boulder Creek in the Slana-'rok district, but no activity was reported at the property in 1950. Frank Barrett prospected on the old Cameron property, a gold lode on Mosquito Fork of the lortymile liver. Robert Stone and associates developed the Eagle creek quartz lode near Medfrat, and moved in additional supplies ind exuipment.

There was but little lode mining or prospecting in the second division during the biennium. In the Solomon area, the Big Tiurrah mine was taken over in 1950 by T. P. Lane of the rionter mining family, and plans were to rework the tailings of previous operations by cyanidation. A cyanide plant was a)dered and received in the fail of 1950 that was expected to l.e erected and operated during 1951. Elsewhere in the area, a bismuth lode prospect on Charley Creek, tributary of sinuk River was being developed by Margraf and Kolowski of Nome. fred Crane did some prospect work on a tin lode at Cape Mounain in the York district in 1949 but was not active in 1950. Other lode operations in the division consisted only of assessment work and a little prospecting.

\section{PRODUCTION}

Mineral production of Alaska in 1948, 1949, and preliminary stimates for 1950, as compiled by Alfred L. Ransome of the Economics Division, U. S. Bureau of Mines Region I, Juneau, Alaska, is shown in Table I. There was a steady increase over he previous biennium in the total value of all minerals produced, although production of gold in 1949 was somewhat lower than for either of the two preceding years. Valuation of the increased output of coal and platinum in 1949 more than of fset the decrease rom the previous year in gold production. Tonnage of coal profiuced in 1949 exceeded by some 25,000 tons the previous reeord set in 1948, and again dropped a little below the 1948 level in 3950 .

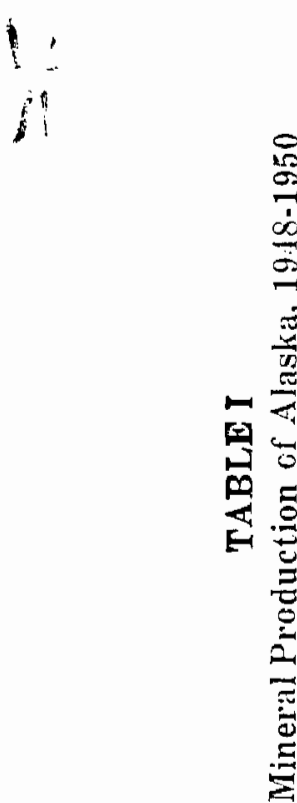

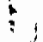

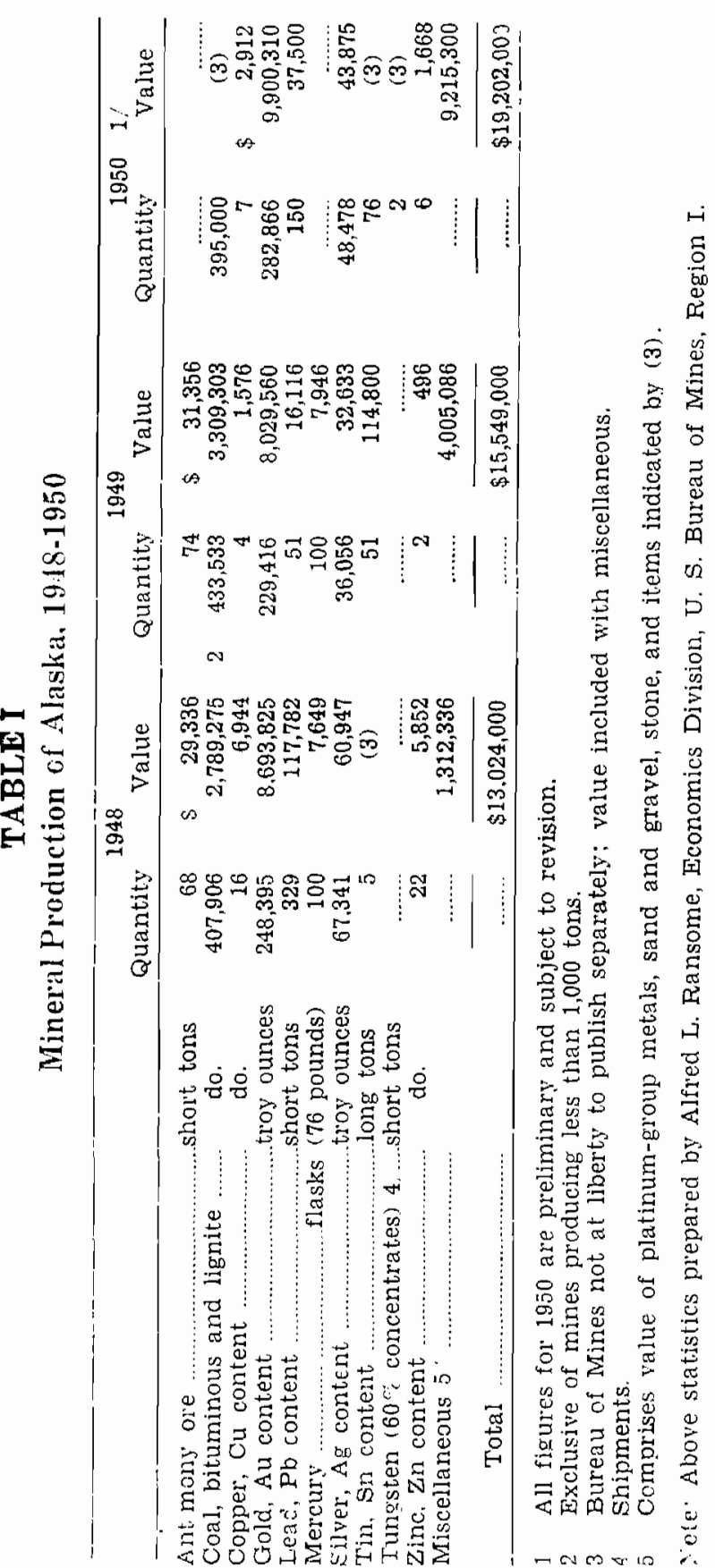




\section{METAL PRICES}

The following table, published on January 4, 1951 by E. and M. J. Metal and Mineral Markets, shows comparative prices of the more common metals for the two years of the biennium. There was a decided upward trend in prices of base and other metals required in the preparedness program that was under way at the end of the biennium. A few of the quotations on January 3, 1951 were: Copper, domestic refinery-24.2 $\dot{\mathrm{Ib}}$, export refinery-24.425\& lb.; Tin, New York-151 6 lb.; Lead, New York-17\% lb., St. Louis-16.8 4 lb.; Zinc, East St. Louis17.54 1b.; Silver, New York-80\% oz., Treasury price on newly mined--90.5c oz.; Platinum, wholesale- $\$ 90$ oz., sales to consumers- $\$ 93$ oza; Quicksilver, New York- $\$ 150 @ \$ 153 \quad 76-1 \mathrm{lb}$. thask.

\section{TABLE II}

Yearly Average Price-1949-1950 (E. \& M. J. Averages)

\begin{tabular}{|c|c|}
\hline & \\
\hline gestic & 19202 \\
\hline Copper, export, f.o.b. refinery, c/lb. & 19.421 \\
\hline Lead, common, New York, c/lb. ... & 15.364 \\
\hline Lead, common, St. Louis, c/lb. ....... & 15.172 \\
\hline Zinc, Prime Western, St. Louis, c/lb. & 12.144 \\
\hline Tin, Straits, New York, c/lb. & 99.336 \\
\hline Silver, foreign, New York. c/oz. ........ & 71.930 \\
\hline Quicksilver (per flask 76-1b.) & $\$ 79.458$ \\
\hline $\begin{array}{l}\text { Antimony, domestic, New York (cases), } \\
\text { c/lb. }\end{array}$ & 40.299 \\
\hline Platinum, $x$ & \\
\hline Cadmium (producers' quotation), $\mathrm{c} / \mathrm{lb}$. & 200.00 \\
\hline Aluminum, 99 plus percent, ingot, $\mathrm{c} / \mathrm{lb}$. & 17.0 \\
\hline Magnesium, ingot, $\mathrm{c} / \mathrm{lb}$. & 20.500 \\
\hline olectrolvitin & \\
\hline
\end{tabular}

1950
21.235
21.549
13.296
13.096
13.866
95.539
74.169
$\$ 81.258$
30.906
$\$ 76.556$
216.840
17.713
22.043
44.792

\section{EMPLOYMENT AND ACCIDENTS AT MINES}

The following Table III reveals the trend of employment in the mining industry from 1914, the first year for which records are available, through 1950 . Accidents and employment at the various types of mines are shown for each year of the biennium in Table IV. The number of man-shifts, number of accidents, and resulting time lost at mines of various types in Alaska, during (ach year for which records are available, are indicated in Table V.
TABLE III

Employment at Mines, 1914 to 1950 , Inclusive Number of Men Employed at:

\begin{tabular}{|c|c|c|c|c|}
\hline Year & Placers & $\begin{array}{l}\text { Lode Mines and } \\
\text { Milling Plants }\end{array}$ & $\begin{array}{l}\text { Coal and } \\
\text { Other Mines }\end{array}$ & Totals \\
\hline 1914 & 4,400 & 3,500 & 140 & 8,040 \\
\hline 1915 & 4,400 & 3,850 & 160 & 8,410 \\
\hline 1916 & 4,050 & 4,200 & 340 & 8,590 \\
\hline 1917 & 3,550 & 3,220 & 270 & 7,040 \\
\hline 1918 & 1,000 & 1,897 & 400 & 5,297 \\
\hline 1919 & 2,180 & 1,757 & 310 & 4,247 \\
\hline 1920 & 1,990 & 1,880 & 360 & 4,230 \\
\hline 1921 & 2,150 & 1,681 & 400 & 4,231 \\
\hline 1922 & 2,198 & 1,623 & 280 & 4,101 \\
\hline 1923 & 2,080 & 1,500 & 270 & 3,851 \\
\hline 1924 & 2,500 & 1,978 & 175 & 4,653 \\
\hline 1925 & 2,700 & 1,745 & 116 & 4,561 \\
\hline 1926 & 2,332 & 1,663 & 108 & 4,103 \\
\hline 1927 & 2,325 & 1,930 & 114 & 4,141 \\
\hline 1928 & $\ldots \ldots \ldots \ldots \ldots$ & 1,668 & 109 & 4,011 \\
\hline 1929 & 2,354 & 1,605 & 89 & 4,048 \\
\hline 1930 & 2,220 & 1,502 & 98 & 3,820 \\
\hline 1931 & 2,163 & 1,323 & 78 & 3,564 \\
\hline 1932 & 2,180 & 1,496 & 78 & 3,754 \\
\hline 1933 & 2,063 & 1,246 & 68 & 3,377 \\
\hline 1934 & 2,195 & 1,451 & 79 & 3,725 \\
\hline 1935 & 2,323 & 1,665 & 89 & 4,077 \\
\hline 1936 & 2,605 & 1,867 & 105 & 4,577 \\
\hline 1937 & $\ldots, 3, \mathbf{1 3 6}$ & 1,957 & 92 & 5,185 \\
\hline 1938 & 3,470 & 2,071 & 218 & 5,759 \\
\hline 1939 & \begin{tabular}{l}
3,928 \\
\hdashline-1
\end{tabular} & 1,986 & 229 & 6,143 \\
\hline 1940 & 4,240 & 1,974 & 149 & 6,363 \\
\hline 1941 & $\quad 3,965$ & 1,805 & 218 & 5,988 \\
\hline 1942 & 2,175 & 1,065 & 249 & 3,489 \\
\hline 1943 & $\ldots \quad 556$ & 581 & 312 & 1,449 \\
\hline 1944 & -1....... 658 & 489 & 393 & 1,540 \\
\hline 1945 & 903 & 238 & 309 & 1,450 \\
\hline 1946 & 1,694 & 446 & 334 & 2,474 \\
\hline 1947 & 1,824 & 384 & 280 & 2,488 \\
\hline 1948 & 1,938 & 309 & 267 & 2,514 \\
\hline 1949 & 1,838 & 262 & 323 & 2,423 \\
\hline 1950 & 1,722 & 243 & 297 & 2,262 \\
\hline
\end{tabular}


TABLE IV

Summary of Accidents and Employment at Mines in Aliskis 19.19-1950

\section{(1949)}

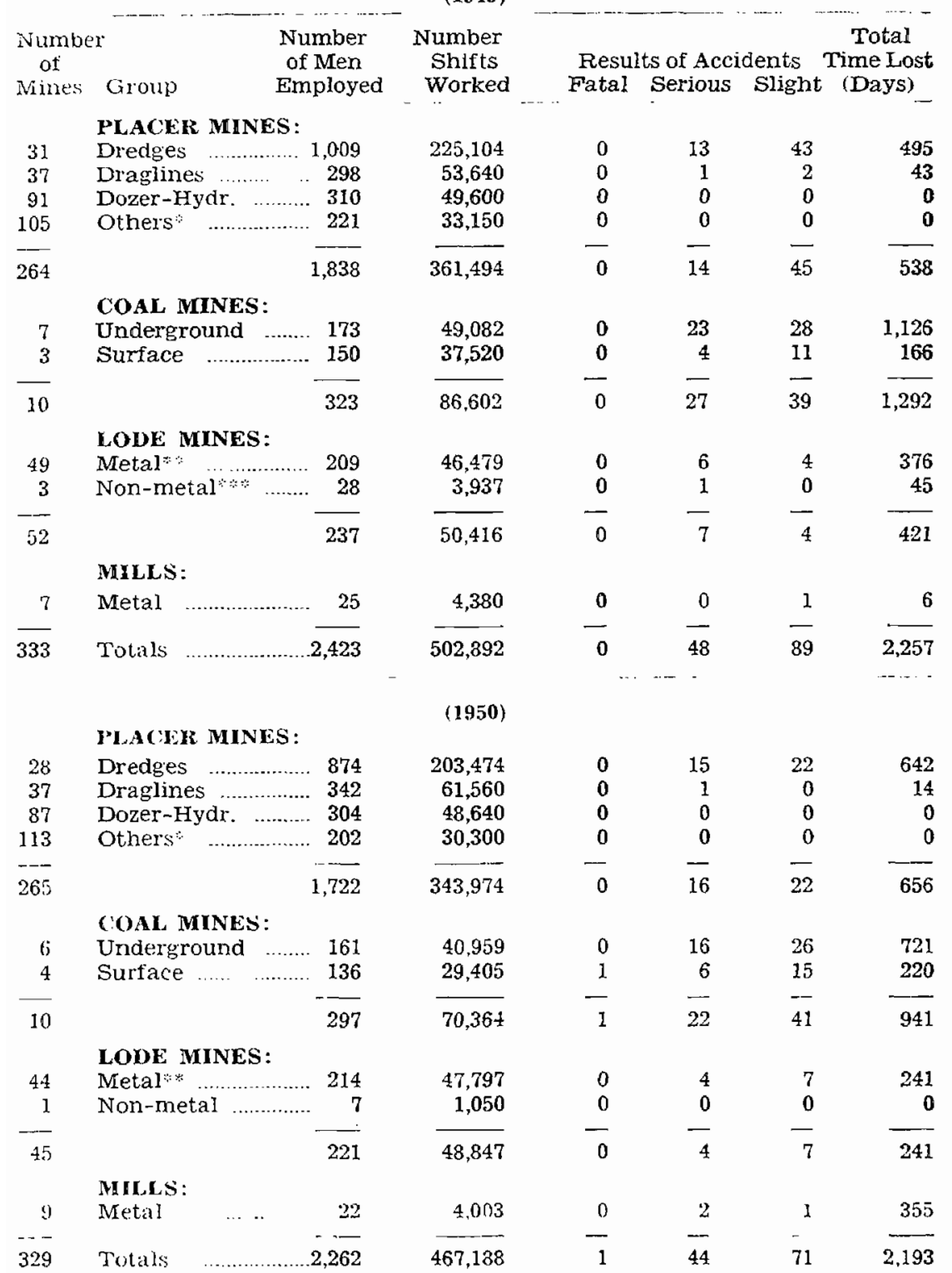

\section{Fatality}

Only one fatality resulted from accidents at mines in Alaska auring the biennium. Austin E. Lathrop, prominent pioneer businessman and principal owner of the Healy River Coal Corporation, was killed at the mine camp on July 26, 1950. A loaded railroad car struck and ran over "Cap," as he was affectionately known by friends and employees, during switching operations in the mine yard at Suntrana, causing instantaneous death.

"Includes hydraulic, shovel-in, drift, snipe and prospectors.

Includes prospectors and intermittent operations.

Includes quarry. 
TABLE $V$

summary of Man-Shifts Worked, Fatal and Non-Fatal Accidents, and Time Lost in All Mines in Alaska

\begin{tabular}{|c|c|c|c|c|c|c|c|c|c|c|c|c|}
\hline Year & $\begin{array}{r}1 \\
\text { Placer } \\
\text { Mines } \\
\end{array}$ & $\begin{array}{c}\text { n-Shifts Wo } \\
\text { Lode Mines } \\
\text { and Mills }\end{array}$ & $\begin{array}{l}\text { at Coal } \\
\text { Mines }\end{array}$ & $\begin{array}{l}\text { Placer } \\
\text { Mines }\end{array}$ & $\begin{array}{l}\text { Fatalities } \\
\text { Lode Mines } \\
\text { and Mills }\end{array}$ & $\begin{array}{c}\text { Coal } \\
\text { Mines }\end{array}$ & $\begin{array}{l}\text { Non- } \\
\text { Placer } \\
\text { Mines } \\
\end{array}$ & $\begin{array}{l}\text { Fatal Accid } \\
\text { Lode Mines } \\
\text { and Mills }\end{array}$ & $\begin{array}{l}\text { lents } \\
\text { Coal } \\
\text { Mines }\end{array}$ & $\begin{array}{l}\text { Time } \\
\text { Placer } \\
\text { Mines }\end{array}$ & $\begin{array}{l}\text { Lost (Days } \\
\text { Lode Mines } \\
\text { and Mills }\end{array}$ & $\begin{array}{l}\text { Soal } \\
\text { Mines }\end{array}$ \\
\hline 1912 & & & & 6 & 6 & & & & & & & \\
\hline 1913 & & & & 10 & 15 & & & & & & & \\
\hline 1914 & & & & 5 & 14 & & & & & & & \\
\hline 1915 & & & & 4 & 19 & & & & & & & \\
\hline 1916 & & & & 7 & 22 & & 27 & 736 & & & & \\
\hline 1917 & & & & 9 & 24 & & 11 & 705 & & & & \\
\hline 1918 & & & & 1 & 12 & & 0 & 199 & & & & \\
\hline 1919 & & & & 0 & 13 & & 5 & 350 & 5 & & & \\
\hline 1920 & & & & 0 & 9 & & 0 & 302 & & & 2,831 & \\
\hline 1921 & & 568,615 & 103,389 & 0 & 12 & & 0 & 248 & & & 3,519 & 471 \\
\hline 1922 & & 537,180 & 55,309 & 0 & 5 & 0 & 0 & 252 & & & 4,344 & 250 \\
\hline 1923 & 84,948 & 618,359 & 66,927 & 2 & 9 & 0 & 7 & 230 & 42 & 394 & 3,991 & 673 \\
\hline 1924 & 117,545 & 468,890 & 51,398 & 0 & 16 & 0 & 30 & 327 & 6 & 560 & 4,882 & 75 \\
\hline 1925 & 405,000 & 592,326 & 34,353 & 0 & 6 & 0 & 0 & 303 & 5 & No report & 5,639 & 109 \\
\hline 1926 & 418,744 & 563,992 & 51,398 & 1 & 6 & 1 & 90 & 365 & 10 & 1,042 & 5,308 & 75 \\
\hline 1927 & 418,235 & 555,155 & 34,915 & 2 & 7 & 1 & 178 & 259 & 13 & 3,267 & 4,819 & 445 \\
\hline 1928 & 445,707 & 559,081 & 32,766 & 3 & 6 & 0 & 152 & 302 & 2 & 2,048 & 5,981 & 19 \\
\hline 1929 & 420,249 & 524,836 & 25,525 & 5 & 9 & 0 & 142 & 255 & 6 & 1,657 & 4,301 & 197 \\
\hline 1930 & 484,301 & 486,515 & 30,101 & 0 & 7 & 0 & 123 & 271 & 7 & 1,096 & 3,979 & 221 \\
\hline 1931 & 437,573 & 425,201 & 22,129 & 0 & 6 & 0 & 92 & 167 & 5 & 1,251 & 2,668 & 101 \\
\hline 1932 & 441,335 & 445,876 & 22,267 & 0 & 5 & 0 & 67 & 163 & 14 & 765 & 2,630 & 250 \\
\hline 1933 & 437,267 & 403,021 & 19,805 & 1 & 7 & 0 & 90 & 177 & 2 & 1,077 & 2,381 & 9 \\
\hline 1934 & 478,908 & 443,265 & 20,514 & 0 & 6 & 0 & 95 & 220 & 7 & 1,313 & 3,784 & 201 \\
\hline 1935 & 499,765 & 458,440 & 23,571 & 2 & 6 & 0 & 116 & 266 & 12 & 1,250 & 4,372 & 291 \\
\hline 1936 & 496,370 & 515,105 & 27,285 & 2 & 8 & 0 & 89 & 284 & 8 & 1,014 & 3,780 & 149 \\
\hline 1937 & 547,748 & 548,929 & 25,267 & 2 & 2 & 16 & 129 & 298 & 14 & 1,733 & 5,007 & 407 \\
\hline 1938 & 607,624 & 595,520 & 27,744 & 2 & 5 & 0 & 112 & 351 & 20 & 1,365 & 5,091 & 423 \\
\hline 1939 & 683,624 & 548,121 & 26,643 & 1 & 3 & 0 & 158 & 302 & 15 & 2,263 & 4,247 & 488 \\
\hline 1940 & 718,153 & 552,579 & 34,450 & 4 & 4 & 0 & 162 & 313 & 29 & 1,999 & 4,260 & 721 \\
\hline 1941 & 657,142 & 517,347 & 54,779 & 1 & 1 & 0 & 151 & 325 & 38 & 1,978 & 5,069 & 630 \\
\hline 1942 & 358,185 & 300,785 & 68,593 & 2 & 2 & 2 & 72 & 149 & 41 & 1,129 & 3,002 & 746 \\
\hline
\end{tabular}

\begin{tabular}{|c|c|c|c|c|c|c|c|c|c|c|c|c|}
\hline 1943 & 82,780 & 155,370 & 84,694 & 0 & 3 & 1 & 1 & 82 & 37 & 54 & 1,338 & 635 \\
\hline 1944 & 98,117 & 81,246 & 101,609 & 0 & 1 & 0 & 0 & 18 & 89 & 0 & 386 & 2,057 \\
\hline 1945 & 145,260 & 52,224 & 84,523 & 0 & 0 & 3 & 5 & 2 & 64 & 22 & 10 & 1,417 \\
\hline 1946 & 297,529 & 116,670 & 82,303 & 0 & 1 & 1 & 44 & 12 & 75 & 521 & 131 & 952 \\
\hline 1947 & 351,916 & 85,361 & 80,691 & 1 & 1 & 1 & 65 & 8 & 47 & 869 & 110 & 646 \\
\hline 1948 & 390,566 & 66,602 & 74,273 & 0 & 0 & 1 & 55 & 7 & 48 & 1,003 & 322 & 613 \\
\hline 1949 & 361,494 & 54,796 & 86,602 & 0 & 0 & 0 & 59 & 12 & 66 & 538 & 427 & 1,292 \\
\hline 1950 & 343,974 & 52,850 & 70,364 & 0 & 0 & 1 & 38 & 14 & 63 & 656 & 596 & 941 \\
\hline
\end{tabular}


LIST OF MINING OPERATIONS IN ALASKA. 1950

\begin{tabular}{|c|c|c|c|c|}
\hline Name and Address of Operator & Location & Precinct & $\begin{array}{l}\text { Type of } \\
\text { Operation }\end{array}$ & \\
\hline Adamlk, Martin, Circle & Boulder Or., trib. Coal Cr. & Circle & Hydraulic & 1 \\
\hline Agoff, Harry, Flat & Prince Cr. & Otter & Bulldozer-hydraulic & 5 \\
\hline $\begin{array}{l}\text { Alaska Exploration \& Mining } \mathrm{Co}_{1}, \\
\text { Talkeetna }\end{array}$ & Bird $\mathrm{Cr}$. & Talkeetna & Hydraulic & 3 \\
\hline Alaska Iron Company, Haines & Near Klukwan & Skagway & \multicolumn{2}{|l|}{$\begin{array}{l}\text { Road construction and } \\
\text { development }\end{array}$} \\
\hline Alaska Juneau Gold Mining Co., Juneau & Alaska Juneau, Juneau & Juneau & $\begin{array}{l}\text { Gold lode and mill } \\
\text { (Maintenance only) }\end{array}$ & 31 \\
\hline Alaska Matanuska Coal $\mathrm{Co}_{0 .}$ Anchorage & $\begin{array}{l}\text { Premier Mine, Moose Creek. Matanuska } \\
\text { Field }\end{array}$ & Palmer & \multicolumn{2}{|l|}{ Coal mine development 3} \\
\hline Alaska Native Service, Juneau & Barrow \& Wainwright & Noatak-Kobuk & Coal mine & 15 \\
\hline $\begin{array}{l}\text { Alaska-Pacific Consolidated Mining } \\
\text { Co., Wasilla }\end{array}$ & Fishhook Cl., Willow Cr. Dist. & Wasllla & Lode gold anc mill & 50 \\
\hline $\begin{array}{l}\text { Alaska Placer Co, Nome or } 327 \text { Colman } \\
\text { Bldg., Seattle } 4, \mathrm{Wn} \text {. }\end{array}$ & Niukluk R., Council Dist. & C. Nome & Gold Dredge & 15 \\
\hline Alder Creek Mining Co, Meehan & Fairbanks Cr. & Falrbanks & $\begin{array}{l}\text { Dragline-bulldozer- } \\
\text { hydraulic }\end{array}$ & 15 \\
\hline Alluvial Golds, Inc., Fairbanks & Woodchopper Cr. & Circle & $\begin{array}{l}\text { Gold dredge mainte- } \\
\text { nance }\end{array}$ & 1 \\
\hline Amero, A. W., Chandalar & Big Cr., Chandalar Dist. & Falrbanks & Sniping & 1 \\
\hline Amund, Otto, Eagle & Fox Cr., trib. Seventymile R. & Eigle & Hydraulic & 1 \\
\hline Amy Creek Mning Co., Falrbanks & Amy $\mathrm{Cr}$. & Fairbanks & $\begin{array}{l}\text { Stripping \& mainte- } \\
\text { nance }\end{array}$ & 1 \\
\hline
\end{tabular}

Anderson, Ellls, Chandalar

Ainderson, Luoto \& Frienze, Nome

Atwood Mining Co., Chicken

Awe Mining Co., Flat

Backstrom, Gus, Flat

Balabanoff, N. R., Talkeetna

Baldwin, Jim, Nome

Barret, Frank, Chicken

Bartholomae Oil Corp., Los Angeles, California

Bauer, Richard \& Calich E., Eagle

Beaton, Neal, Ophir

Benick, Ed, Nome

Berg, L. C., Sitka

Berail, Phillip, Circle

Berry Dredging Co., 1704 Sutter st., San Francisco 4, Calif.

Big Hurrah Quartz Mine, Nome, or 2220 N. 13th St., Phoenix, Ariz.

Blasher, Frank, Hyder

Bleecker, F. C., Fairbanks
Tobin $\mathrm{Cr}$, Chandalar Dist.

Hammon $\mathrm{Cr}$., trib. Inmachuk $\mathrm{R}$.

Stonehouse Cr. bench, Fortymile Dist.

Marvel Cr.

Head of Flat Cr.

Nugget $\mathrm{Cr}$.

Sweepstakes Cr., trib. Peace R.

Mosquito Fork, trib. Fortymile $R$.

Ryan Lode, Ester Dome

Crooked Cr, trib. Seventymile R.

Ganes $\mathrm{Cr}$. bench

Ophir Cr., trib. NiukJuk $\mathrm{R}$.

Berg Basin, Wrangell Dist.

Colorado $\mathrm{Cr}$.

Mammoth $\mathrm{Cr}$.

Big Hurrah Cr., trib. Solomon $\mathrm{R}$

Cantu \& upper Texas Cr.

First Chance Cr.
Fairbanks

Fairhaven

Fairbanks

Kuskokwim

Otter

Talkeetna

C. Nome

Fairbanks

Fairbanks

Eagle

Innoko

C. Nome

Wrangell

$i=i$

Circle

Circle

C. Nome

Hyder

Fairbanks

$\begin{array}{lr}\text { Placer drift } & 1 \\ \text { Bulldozer-hydraulic } & 3 \\ \text { Bulldozer } & 1 \\ \text { Dragline-bulldozer } & 6 \\ \text { Hydraulic } & 3 \\ \text { Sniping } & 2 \\ \text { Bulldozer-hydraulic } & 4 \\ \text { Gold lode develop- } & \\ \text { ment } & 1 \\ \text { Gold lode (mainte- } & \\ \text { nance) } & 1 \\ \text { Hydraulic } & 2 \\ \text { Bulldozer-hydraulic \& } \\ \text { Gold dredge } & 7 \\ \text { Shovel-in } & 1 \\ \text { Diamond-drilling \& de- } \\ \text { velopment lead-zinc } \\ \text { lode } \\ \text { Groundsluice } & 6 \\ \text { Gold dredge } & 1 \\ \text { Gold lode \& mill } & 4 \\ \text { Lode prospecting } & 1 \\ \text { Hydraulic stripping } & 1\end{array}$


Blundell, J. B., Big Lake

Bodis, George, Nome

Bonanza Mining Co., Chisana

Bott, Earl \& Lyle, Big Lake

Bouquier, John, Flat

Bowman, Harry, Iliamna

Bradley, C. W., Talkeetna

Brinker-Johnson Mining Co., $215 \mathrm{~N}$ Carson st., Carson City, Nev.

Brown, R. A., Chicken

Bufvers, John, Ketchikan

Burns, J. \& Sons, Falrbanks

Callahan Zinc-Lead Co., 100 Park Ave., New York 17, N. Y.

Cannon, Robert, Teller

Canyon Creek Mining Co., Jens Kvamme \& Sons

Carlo, Wm., \& May, John, Ruby

Casa de Paga Gold Co., 1106 Hoge Bldg., Inmachuk $R$. Sea.tle, Wn.

Chappell, Oliver L., Wiseman

Chititu Mines, McCarthy

Chrome Queen Mining Co., Seward

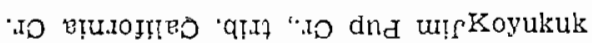

Dick Cr.

Bonanza $\mathrm{Cr}$.

Eight Mile Cr., trib. Bettles R.

Happy $\mathrm{Cr}$.

Portage Cr., trib. L. Clarke

Upper Cache Cr.

Caribou Cr.. Salcha R. Dist.

Uhler $\mathrm{Cr}$,, trib. Fortymlle $\mathrm{R}$.

Prince of Wales I. near Kasaan

Homestake $\mathrm{Cr}$, trib. Totatlanika $\mathrm{R}$.

Livengood Creek

Birch Cr., trib. American R.

Canyon $\mathrm{Cr}$.

Ophir Cr., trib. Sulatna R.

Thompson Gulch, trib. Nolan R.

Rex \& Chititu Crs .

Red Mountain, Kenai Penin.
C. Nome

Chitina

Koyukuk

Otter

Iliamna

Shovel-in \& W. dilft 1 .

Bulldozer-dragline 2

Hydraulic

Shovel-in \& groundsluice

Bulldozer-hydraulic

Talkeetna

Fairbanks

Fairbanks

Ketchikan

Nenana

Fairbanks

C. Nome

Bethel

Nulato

Fairhaven

Koyukuk

McCarthy

Seldovla

Bulldozer-hydraulic

Hydraulic

Gold dredge

Bulldozer-hydraulic

Silver-gold prospect

Bulldozer-hydraulic

Gold dredge maintenance, stripping and thawing

Bulldozer-hydraulic

Bulldozer-hydraulic

Bulldozer-hydraulic 3

2 Gold dredges

Hydraulic

Placer drift
Cleary Hill Mines, Inc., Fairbanks

Coffin, W. H., Deering

Collinsville Mines, Box 547, Anchorage

Colorado Cr. Mining Co., Ophir

Connell, Paul A., Circle

Cripple Creek Coal Co., Box 622, Fairbanks, Alaska

Cripple Creek Mining Co., Anchorage

Dahl, Ben, Fairbanks

Dahl, Robert, Talkeetna

Danich, Joe, Anchorage

Davis, Joe, Chisana

Dawson, Wendell, Box 2384, Ketchikan Deadwood Mining Co., Circle Hot Springs

Dean, Tom, Hot Springs

Degnan, Joe, Ophir

Dempsey \& Edwards, Nome

Diamond Coal Co., Box 890, Fairbanks

Dinan, Frank, Rampart

Dittman, David, Falrbanks
Sullivan Cr. \& Tofty Gulch Kugruk R.

Mills Cr. \& lower Twh Cr.

Colorado Cr., Cripple Dist.

Hughes Mtn., N. bank Yukon R.

Cripple Cr., trib. Healy R.

Upper Cripple $\mathrm{Cr}$, near Folger

Bear Cr., trib. Buckland $\mathbf{R}$.

Nugget $\mathrm{Cr}$.

Jewel \& Monarch Mines, Girdwood

No. 2 Little Eldorado $\mathrm{Cr}$.

Harris $\mathrm{Cr}$., Prince of Wales I.

Lower Miller Cr.

Little Cr.

Casadepaga R., trib. Nluluk R.

Norris-Parris permit. Healy $R$.

Florida $\mathrm{Cr}$

Skoogy $\mathrm{Cr}$.
Hot Springs

Fairhaven

Talkeetna

Innoko

Circle

Nenana

Innoko

Falrhaven

Talkeetna

Anchorage

Chitina

Ketchikan

circle

Hot Springs

Innoko

C. Nome

Nenana

Rampart

Falrbenks
Dragline-hydraulic 8

Hydraulic

Dragline-washing plant

Dragline-bulldozerhydraulic

Lode prospecting

Strip coal mine

Dragline-bulldozer-hydraulic

Bulldozer-hydraulic Sniping

Assessment on gold
lode

Shovel-in

Gold lode with mill

Dragline-bulldozer

Placer drift

Dragline-bulldozerhydraulic

Gold dredge

Strip coal mine

Placer drift \& groundsluice

Bulldozer-hydraultc 
Dobson, H., Nome

Douglas, J., Marshall

Doyle. Jere, Hot Springs

Eagle Creek Mine, Medfra

Eisenmenger, Wm., Fairbanks

Englebritzen, Wm., Fairbanks

Engstrom, Herbert, Nome

Engstrom \& McDonald, Nome

Erickson, Helvor, Talkeetna

Evan Jones Coal Co., Box 619, Anchorage

Evans, Orville, Fairbanks

Fern Gold Mining Co., Anchorage

Four-A Mining Co., Falrbanks

Francis, Earl \& Coble, Joe, Falrbanks

Franklin Mining Co., Fairbanks

Frasca, John \& Gibson, Chas., Miller House

$F_{1}$ y Bros., Palmer

Giv'ler, Grover, \& Myklebust, John, Ophir

G. ass \& Taylor, Nome

Gold Mint Mines, Hope, or 621 s. Hope St., Los Angeles, Callf.
American Cr., Pt. Clarence Dist.

Upper Willow Cr.

Lower New York Cr.

Vicinity of Medfra

Tibbs Cr., trib. Goodpaster R.

Pedro $\mathrm{Cr}$.

Basin Cr., trib. Nome $R$.

Basin Cr., trib. Nome R.

Cache $\mathrm{Cr}$.

Jonesville, Matanuska FHeld

Van Curler Bar

Fern Mine, Archangel Cr.

Pedro Creek area

Lower Eureka Cr.

Chicken Cr., trib. Fortymile R.

Eagle Cr.

Valdez Cr.

Little $\mathrm{Cr}$.

Solomon $\mathbf{R}$.

Nearhouse property, Palmer Or.
C. Nome

Wade-Hampton

Hot Springs

Mt. McKinley

Falrbanks

Fairbanks

C. Nome

C. Nome

Talkeetna

Palmer

Falrbanks

Wasilla

Fairbanks

Hot Springs

Fairbanks

Circle

Talkeetna

Innoko

C. Nome

Seward
Groundsluice

Shovel-in

Bulldozer-hydraulic 3

Gold lode development 2

Gold lode prospect 1

Sniping 1

Bulldozer-hydraulic 3

Placer drilling 2

Hydraulic

Bituminous coal mine

$\&$ washery

Bulldozer

Gold lode \& mill

Bulldozer-hydraulic 3

Silver lead prospect 1

Bulldozer-hydraulic 2

Dragline-bulldozerhydraulic

Bulldozer-hyäraulic

Repairing pipeline 3

Dragline-bulldozerhydraulio

Bulldozer-hydraulic 3

Gold lode development 1
Gold Placers, Inc., Eairbanks

Goodnews Bay Mining Co., Platinum

Goodwick \& Tronstad, Kobuk P. O.

Granger, D., \& Dragon, L., Chicken

Grant Mining Co., Nome

Grant Mining Co., Nome

Grant, O. M., Fairbanks

Grubstake Mine, Inc., Wasilla

Hamberg \& Glliska, Talkeetna

Hard \& Utolia, Folger

Harrison Creek Mining Co., Muler House

Hassel, Harold, Fairbañks

Hatten \& Turner, Flat

Havenstrite Mining Co., 811 W. 7th St, Mud Cr, Los Angeles 14, Calif.

Hayes \& Whiteley, Douglas

Hayes \& Whiteley, Douglas

Healy River Coal Corp., Suntrana

Helcolicon Mines, Inc., Ktana

Pass Cr.
Coal Cr., Circle Dist.

Circle

Salmon R. \& tribs., Goodnews Bay Dist. Bethel

Dahl Cr.. trib. Kobuk R.

South Fork Fortymile $R$.

Macklin Cr., trib. Kougarok $\mathbf{R}$.

Coffee Cr., Kougarok Dist.

Happy Cr., Ester Dome

Grubstake $\mathrm{Cr}$.

Bear Cr., Cripple area

Harrison $\mathrm{Cr}$.

Ready Bullion Cr., trib. Ester Cr.

Willow Cr.

Noatak-Kobuk

Fairbanks

C. Nome

C. Nome

Fairbanks

Wasilla

Talkeetna

Innoko

Circle

Fairbanks

Otter

Fairhaven

Alaska Juneau dump

Juneau

Chichagof Mine, Chichagof I.

Suntrana Mine, Healy $\mathrm{R}$.

Sitka

Nenana

Salmon R. \& Klery Cr., tribs. Kobuk R. Noatak-Kobuk
Gold dredge

Platinum dredge

Dragline-bulldozerwashing plant

Hydraulic

Bulldozer-hydraulic

Bulldozer-hydraulic

Bulldozer-hydraulic

Gold lode maintenance I

Gold lode and mill

Hydraulic

Dragline-bulldozer

Hydraulic-bulldozer

Dragline-bulldozerhydraulic

Dragline-bulidozerhydraulic

Gold dredge

Dragline-bulldozerhydraulic

Truck-shovel-sluice

Re-milling tailings

Subbituminous coal mine screening plant

Placer drilling \& gold dredge 
$\mathrm{H} \& \mathrm{H}$ Mining Co., Teller

Hi Yu Mining Co., Frairbanks

Hirst-Chichagof Mining Co., Kimshan Cove, or 415 Seventh Ave., Seattle

Homer Coal Corp., Homer

Hosler, D. G. \& Elmer, Anchorage

Houston Coal Co, Anchorage

Houston, Alexander, Nome

Hovely, Otto, Hot Springs

Hunter Creek Mining Co., Kotzebue or Nome

Hunter Creek Mining Co., Fairbanks

Iditarod Operating Co., Fairbanks

Innoko Dredging Co., Ophir

Jackson, Douglas \& Beistline, Earl, College

Jackson, Nels, Fairbanks

Jenkins, Fred F. \& Assoc., Eagle

Johanssen, Ed, Chicken

Johnson, Elmer, Ketchikan

Johnson, Frank, Kobuk P. O.

Johnson, H., Teller
Million Cr., trib. Windy Cr., trib. American $\mathrm{R}$.

HI Yu Mine, Fairbanks Cr.

Kimshan Cove, Chichagof I.

McNally property, Cook Inlet Field

Moose Cr., trib. Kantishna $\mathrm{R}$.

Tucker-Peterson. Permit, Houston

Dahl Cr., trib. Quartz Cr.

Fergeson Cr., trib. Cache Cr.

Hunter Cr., trib. Kiwallk R.

Upper Hunter $\mathrm{Cr}$.

Golden Cr., trib. Illinois Cr.

Upper Ganes Cr.

Cleary Hill Mine

\section{Totatlanika $\mathbf{R}$}

Flume Cr., trib. Seventymile $R$. Ingle Cr., trib. Mosquito Fork George Inlet

Dahl Cr., trib. Kobuk R.

Gold Run Cr., trlb. Bluestone R.

\begin{tabular}{|c|c|c|}
\hline C. Nome & Buldozer-hydraulic & 2 \\
\hline Falrbanks & $\begin{array}{l}\text { Gold lode maintenance } \\
\& \text { prospect }\end{array}$ & 2 \\
\hline Sitka & $\begin{array}{l}\text { Rehabilitation gold } \\
\text { lode \& mill }\end{array}$ & 6 \\
\hline Seldovia & Coal mine development & 5 \\
\hline Fairbanks & Bulldozer & 3 \\
\hline Wasilla & Bituminous coal & 8 \\
\hline C. Nome & Bulldozer-hydraulic & 2 \\
\hline Hot Springs & Placer drift & 2 \\
\hline Fairhaven & Placer drilling & 2 \\
\hline Rampart & Bulldozer-hydraulic & 4 \\
\hline Ft. Gibbon & Bulldozer-hydraulic & 5 \\
\hline Innoko & Gold dredge & 14 \\
\hline Falrbanks & Gold lode with mill & 2 \\
\hline Nenana & Bulldozer-hydraulic & 2 \\
\hline Eagle & Nickel lode prospect & 2 \\
\hline Fairbanks & Hydraulic & 1 \\
\hline Ketchlkan & $\begin{array}{l}\text { Prospecting \& Assess- } \\
\text { ment work on zine } \\
\text { lode }\end{array}$ & 2 \\
\hline Noatak-Kobuk & Hydraulic & 1 \\
\hline C. Nome & $\begin{array}{l}\text { Placer drift \& shovel- } \\
\text { in }\end{array}$ & 1 \\
\hline
\end{tabular}

Cleary cr.

Trail Cr.

Between Glen Gulch \& Rhode Island Cr. Hot Springs

Smith Cr., trib. Nolan $\mathrm{Cr}$.

Lillian Cr., trib. Livengood $\mathrm{Cr}$.

Miller $\mathrm{Cr}$.

No. 3 Pup, trib. Grubstake Cr.

Sunset Cove, Windham Bay

Knob Cr., Eska area, Matanuska Fleld

Mascot Cr.

Kougarok $\mathrm{R}$

Buster Cr., trib. Nome R.

Pedro Or.

Lake Bay, Prince of Wales, I.

Switch Cr., trib. Deadwood Cr.

High Grade Claims, Fishhook Cr.

Thanksgiving $\mathrm{Cr}$.

Tow'n of Seward

Pedro Dome
Fairbanks

Nulato

Koyukuk

Fairbanks

Circle

Nenana

Juneau

Palmer

Koyukuk

c. Nome

C. Nome

Falrbanks

Ketchikan

Circle

Wasllia

Hot Springs

Seward

Falrbanks

\begin{tabular}{|c|c|}
\hline Bulldozer-hydraulic & 4 \\
\hline $\begin{array}{l}\text { Dragline-bulldozer- } \\
\text { pump }\end{array}$ & 3 \\
\hline Bulldozer-hydraulic & 2 \\
\hline Hydraulic & 2 \\
\hline Hydraulic & 2 \\
\hline Bulldozer-hydraulic & 2 \\
\hline Shovel-in & 1 \\
\hline $\begin{array}{l}\text { Gold-antimony lode } \\
\text { development }\end{array}$ & 2 \\
\hline Coal mine development & 6 \\
\hline Shovel-In & 1 \\
\hline Dragline & 35 \\
\hline $\begin{array}{l}\text { Construction of gold } \\
\text { dredge }\end{array}$ & 2 \\
\hline Bulldozer-hydraulic & 2 \\
\hline $\begin{array}{l}\text { Assessment on copper } \\
\text { lode }\end{array}$ & 2 \\
\hline ydraulic & \\
\hline
\end{tabular}

Gold lode development 1 Bulldozer-hydraulic 1 Gold lode development 2 Gold lode 
Leov, Harry, Flat

Lee Bros. Dredging Co., Nome

Leisman, Hans, Bettles

Leonard, H. H., Seward

Leroy Mining Co., Box 4011, Juneau, or 12715 Aurora Ave., Seattle, Wash.

Lindfors, Hugo \& Bale, Nome

Lindquist \& Carlson

Little Minook Mining Co., Fairbanks

Lindgren, M. \& Assoc., Falrbanks

Lody, Mike, Falrbanks

Long Creek Mining Co., Ruby

Longborg \& Anderson, Box 523, Nome

Lost Chicken Mining Co., Chicken

Lucky Nell Mining Co., 511 Puyallup Ave, Tacoma $2, \mathrm{Wn}$.

McFarland, C. \& Hubbard, W, Ophir

NcMahan, C. J., Nelchina

McShane, O. T., Talkeetna

Miargraf, Kolowsk1 \& Co., Nome

Margraf, Eugene, Nome
Malamute Pup, trib. Otter Cr.

Solomon $\mathrm{R}$.

Rye Cr., trib. Wlld $\mathrm{R}$.

Skilak Iake

Reid Inlet, Glacler Bay

Rocky Mtn, Or., trib. Nome R.

Victor Gulch

Little Minook Cr.

Coffee Dome

Callformia Cr.

Bear Pup, trib. Iong Cr.

Unalakleet

Lost Chtcken Cr., Fortymile Dist.

Prince of Wales L. near Holls

Six Pup, upper Little Cr.

Albert Cr., Nelchina Dist.

Upper Falls Cr.

Chariey Cr., trib. Sinuk R.

Cripple Rlver
Otter

C. Nome

Koyukuk

Seward

Juneau

C. Nome

Innoko

Rampart

Fatrbanks

Nenana

Nulato

St. Michael

Falrbanks

Ketchikan

Innoko

Chitina

Talkeetna

C. Nome

c. Nome
Hydraulic

Gold dredge

Shovel-1n

Antimony lode development

Gold lode \& mill

Bulldozer-hydraulic

Bulldozer-hydraulic

Dragline-bulldozerpump

Gold lode prospect

Groundsluice

Dragline-bulldozerhydraulic

Coal Mining

Bulldozer-hydraulio

Assessment on goldcopper lode

Bulldozer-hydraulic

Bulldozer-hydraulic

Placer Gold development

Bismuth lode prospect 4

Placer drllling
Martin, G. B. Mining Co., Fairbanks Martin, Henry, Circle Hot Springs

Martinson, Olaf, Teller

Matheson, H. \& Savage, P., Ophir

Maurer, Ernest, Fairbanks

Meise, Tony \& Stanton, Haroid, Talkeetna

Meldrum, Wm., Chicken

Midnight Mining Co., Nome

Miller, Frank \& Sons, Wiseman

Miscovich, P., \& Sons, Flat

Miscovich, P. \& Sons, Fatrbanks

Moore Creek Mining Co., Fairbanks

Morelock Mining Co., Fairbanks

Morrison-Knudsen Co., Inc., Falrbanks

Mountain Vlew Gold Mining Co., Ketchikan

Munz, William, Nome

Murphy, John, Ferry

Myrtle Creek Mining Co., Fairbanks

Nashenweng, Louis \& Bliss, Nome
Buckeye Cr., trib. Banner Cr.

Portage Cr.

Gold Run Cr., trib. Bluestone R.

Spruce $\mathrm{Cr}$.

First Chance $\mathrm{Cr}_{1}$, trib. Goldstream Cr.

Ruby Gulch \& Cache $\mathrm{Cr}$.

Chicken Cr.

Skookum Cr.

Sheep Cr., trib. Middle Fork Koyukuk R. Koyukuk

otter $\mathrm{Cr}$.

Flat \& Timber Crs.

Taylor Cr., trib. Holitna R.

Rosie Cr., trib Morelock Cr.

Nome Cr., Tolovana Dist.

Fish Cr, near Hyder

Aggie Cr.

Upper Eva Cr.

Myrtle $\mathrm{Cr}$.

Lower Dahl Cr., Kougarok Dist.
Fairbanks

alrbank

Otter

Nulato

Kuskokwim

Ft. Gibbon

Falrbanks

Hyder

C. Nome

Nenana

Koyukuk

Bulldozer-hydraulic 8

Groundsluice 1

Shovel-In

Dragline-bulldozerhydraulic

Bulldozer-hydraulic

Bulldozer-hydraulic

Bulldozer-hydraulic

Bulldozer-hydraulic

Bulldozer

Dragline-bulldozerhydraulic

Dragline-bulldozerpump

Bulldozer-hydraulic

Bulldozer-hydraulic

Gold dredge mainte nance

Assessment work

Bulldozer-hydraulic

Groundsluice

Dragline-bulldozer

C. Nome 
Nelson \& Fitch, Nome

Nesland, E. \& White, P., Wiseman

New Hope-Hirshey, Seward

New York-Alaska Gold Dredging Corp., Nyac or 41 Broad St., New York

No Grub Mining Co., Fairbanks

Norheim, Hans \& Assoc., Hot Springs

North American Gold Dredging Co., Flat

Northern Tin Co., Nome, c/o Wein Alaska Airline

North Fork Dredging Co., Nome

Novatney, Robert, Juneau

Nugget Mining Co., Talkeetna

Olive Creek Mines, Falrbanks

O'Brien, Jim \& Dunsmuir, Jim, Seward

O'Neil, Frank \& Sroufe, Ward, Box 2000, Anchorage

Ost., L. E., Counctl

P. R. \& H. Mining Co., Frairbanks

Parker, Charles L., Juneau

Pekovich, W. S., Box 529, Juneau

Pennington \& Tyler, Palmer
Nome Beach near Fit. Davls

Vermont Cr., trib. Hammon $R$.

C. Nome

Koyukuk

Hirshey \& Hatcher Mines, Paimer Cr.

Seward

Bear Cr, trib. Tuluksak R.

No Grub Cr., Salcha Dist.

Eureka Creek bench

Otter $\mathrm{Cr}$.

Buck Cr., York Dist.

N. Fk. Kougarok $R$.

Helm Bay

Cache $\mathrm{Cr}$. at mouth Thunder $\mathrm{Cr}$

Olive Cr., trib. Tolovana $R$.

Surprise $\mathrm{Cr}$., trib. Kenal R.

Upper Craigie $\mathrm{Cr}$.

Crooked Cr., trib. Ophlr Cr.

Deadwood Creek

Excursion Inlet

Sentinel Pt., Port Snettisham

Daisy Cr., trib. Tyone R.
Bethel

Fairbanks

Hot Springs

otter

C. Nome

C. Nome

Ketchikan

Talkeetna

Fairbanks

Seward

Wasilla

C. Nome

Circle

Juneau

Juneau

Talkeetna
Shovel-in

Bulldozer-hydraulic 2

Gold lode development 1

2 golde dredges, and 50 dragline-bulldozerhydraulic

Hydraulic

Bulldozer-hydraulic

Gold credge

Dragline-jigs

Gold dredge

Lode gold prospect

Bulldozers

Dragline-bulldozer 5

Groundsluice \& drift 2

Gold lode prospecting 2

Assessment gold placer 2

Bulldozer-hydraulic 4

Lead-silver-copper prospect

Sampling \& staking iron lode

Placer development
Peterson, Hans, Nome

Philpott, L. \& Holdahl, A., Falrbanks

Pierce, James \& Cravey, Chas., Rampart

Pitoff, Geo., Talkeetna

Pitts, Fred, Wiseman

Portage Mining Co., Circle Hot Springs

Porter, Wallace, Haycock

Price, Stanton, Windham

Primer, Paul, Shungnak

Pringle, A. W, Hot springs

Purdy, Fred \& Arthur, Chtcken

Purkeypile, I. W., Poorman

Quigley, E. W., Solomon via Nome

Radak, John, Livengood

Radovan, Martin, McCarthy

Rainbow Mining Co., Nome, Box 266

Reinoski, Frank J., Rampart

Rheims, J. \& Wilke, J., Boundary

Rice, C. F. Co., Teller

Riverside Tungsten Mine, Hyder, or

81-553 Granville St., Vancouver, B.C.

Rosander, T. \& Reed, L., Ophtr
Dome Cr., trib. Iron $\mathrm{Cr}$.

Upper Firth River

Hoosier $\mathrm{Cr}$.

Upper Nugget $\mathrm{Cr}$.

Lake Cr., trib. Big Lake

Portage Cr.

Bear Cr., trib. Buckland $R$.

Spruce Cr., Windham Bay

Lynx $\mathrm{Cr}$,, trib. Kogoluktuk R.

Rhode Island $\mathrm{Cr}$.

Myer's Fk., trib. Chicken Cr., Fortymlle Dist.

Boulder $\mathrm{Cr}$., Tonzona Dist.

Solomon R.

Ruth Cr., Tolovana Dist.

Glacier Cr.

Goose Cr.

Grouse Cr., trib. upper Funter Creek

Squaw Cr., Fortymie Dist.

Sunset $\mathrm{Cr}$.

Salmon R. $7 \mathrm{Mi}$.

Yankee Cr.
C. Nome

Fairbanks

Rampart

Talkeetna

Koyukuk

Circle

Fairhaven

Juneau

Noatak-Kobuk

Hot Springs

Fairbanks

Mt. Mckinley

C. Nome

Falrbanks

McCarthy

C. Nome

Rampart

Fairbanks

C. Nome

Hyder

Innoko
Assessment gold placer 1

Bulldozer

Bulldozer-sluice plate 3

Sniping

Hydraulic

Dragline-bulldozer

Bulldozer-hydraulic 5

Bulldozer-sluice boxes 3

Hydraulic

Bulldozer-hydraulic

Bulldozer-hydraulle 2

Silver-lead prospect 2

Bulldozer-hydraulic 4

Hydraulic

$\underset{\text { Copper lode develop- }}{1}$

Bulldozer-hydraulic 2

Prospecting 1

Bulldozer 2

Bulldozer-hydraulic 3

Lead, silver, gold, tungsten, Lode and mill 32

Dragline-bulldozer-

hydraulic 
Rosenbush, B., Franklin

Ruby Creek Mining Co., Rampart

Rupp, Ray, Ferry

Savage, Patrick, Flat

Schwaesdall, Andy \& Acherson, ' $\mathrm{T}$., Wiseman

Scott, Tolbert, Nome

Sellars, R. W., Chandalar

Silver Bow Mining Co., Nome

Slocum Arm Mining Co, Cobel via Juneau

Smith, F. J., Wiseman

Snowbird Mining Co., Inc., Anchorage, Box 1719

Sourdough Dredging Co., Councll

Stampede Mines, Fairbanks

Stanich \& Stanich, Wiseman

St ock \& Grove, Anchorage

S1:andberg \& Sons, Anchorage

Strandberg \& Sons, Anchorage

Stuver, Jules, Flat

Sunset Mining Co., Anchorage
Fortymile R.

Ruby $\mathrm{Cr}$.

Little Moose Cr.

Flat Cr. \& Willow Cr.

Crevice Cr., trib. John R.

Iron Cr.

Big Cr., Chandalar Dist.

Coffee Cr.

Cox-Bolyan Mine, slocum Arm, Chichagof I.

Spring Cr.

Reed Cr., trib. Little Susitna R.

Ophir Cr.

Stampede Cr., Kantishna Dist.

Porcupine Cr., trib. Koyukuk R.

Geographic Bay

Utopia Cr., trib. Indian $R$.

Candle Cr., Takotna Dist.

Head of Happy $\mathrm{Cr}$.

Lower Cache $\mathrm{Cr}$.

Falrbanks
Rampart
Nenana
Otter

Koyukuk

C. Nome

Falrbanks

C. Nome

Sitka

Koyukuk

Wasilla

C. Nome

Fairbanks

Koyukuk

Iliamna

Ft. Gibbon

Mt. Mckinley

Otter

Talkeetna \begin{tabular}{ll|} 
Sniping & 1 \\
Bulldozer-hydraulic & 2
\end{tabular}

Groundsluice

Dragline-bulldozerhydraulic

Bulldozer-hydraulc

Gold dredge

Bulldozer-hydraulic 10

Bulldozer-hydraulic 3

Assessment on gold lode

Shovel-In

Mill construction

Gold dredge

10

Antimony lode \& mill 3

Bulldozer-hydraulic 2

Pumicite stripping \&

$$
\text { mining }
$$

Dragline-bulldozerWashing plant

6

Gold dredge

Hydraulic

Bulldozer-hydraulic
Swanson Bros., Albert \& Emil, Rampart

'Tanner \& Taylor, Nome

Taraski, A. J., Talkeetna

Tasker, E. \& Bacon, W.

Terrel, Fred, Big Lake

Theisen, Frank \& Farrell, Ed., Wiseman

Thompson, Joe, Iliamna

Thunder Mines, Inc., Box 993, Anchorage

Tillicum Mining Co., Ketchikan

Trinity Mining Co., Nome

Twedt, Ole, Chichagof

Tweet, N. B. \& Sons, Teller

Ulen, Joe \& Pringalo, Sam, Wiseman

U. S. S., R. \& M. Co., 75 Federal St., Boston, Mass.

U. S. S., R. \& M. Co.

U. S. Tin Corp., 201 Jones Bldg., Seattle, Wn.

Uotila \& Hard, Ophl.

Uotila \& Ogriz, Fat

Usibelli Coal Mine, Suntrana

Vanadium Corp. of America, Rifle, Colorado
Hunter Cr.

Rampart

Ophir $\mathrm{Cr}$.

Cache $\mathrm{Cr}$.

Marguerite Cr.

Garnet $\mathrm{Cr}$., trib. Bettles R.

Suckik Cr., trib. John R.

Kijik R., trib. Lake Clark

Thunder $\mathrm{Cr}$.

Dora Lake, Prince of Wales I.

Trinity Cr., trib. Kougarok R.

Klag Bay, Chichagof I.

Kougarok $\mathrm{R}$.

Nolan Cr. bench

Fairbanks Dist.

Nome vicinity

Cassiterite Cr., trib. Lost R., Pt. Clarence Dist.

Ophir $\mathrm{Cr}$.

Slate $\mathrm{Cr}$.

Healy Field

Claim Pt. \& Red Mtn., Kenal Peninsula
C. Nome

Talkeetna

Nenana

Koyukuk

Koyukuk

Iliamna

Talkeetna

Ketchikan

C. Nome

S1tka

C. Nome

Koyukuk

Fairbanks

C. Nome

C. Nome

Innoko

Otter

Nenana

Seldovia

\section{Bulldozer-hydraulic 5}

Prospecting

Hydraulic

Hydraulic

Groundsluice

Buldozer-groundsluice 2

Lead-silver prospect 1

Hydaulic \& prospecting

Lead-zinc prospect

Buldozer-hydraulic 4

Goid lode development 1

Bulldozer-hydraulic 4

Buldozer-hydraulic 2

5 gold dredges $\quad \mathbf{3 3 5}$

3 gold dredges 123

Bulldozer-hydraulic tin placer

Dragline-hydraulicbulldozer

Dragline-bulldozerhydraulic 10

Strip coal mine

Road repair 
Verdin, Ed., Fox

Vogan, Barmey, Teller

Vuyovich, John, Ester

Wade Creek Mining Co., Box 1108, Fairbanks

Wackowitz, Charles \& Fred, Fairbanks

Waldhelm, Geo., Nome

Wallin, Geo., Candle

Wanamaker, H. S., Wiseman

Warwick Mines, Fairbanks

Watkins, R. V., Fairbanks

Weatherall, Geo., Talkeetna

Weaver, Vern, Chicken

Webb, Herman L. Chandalar

Weinard, Fred, Candle

Wells, Cecil, Fairbanks

Wells, John, Ctrcle

Weston, David M., Eagle

Whitmore, R. H., Nome

Willow Creek Mining Co., Marshall

Winder, J. S., Hayrock

Wiurm Bros., Nome

Woodchopper Mining Co., Tofty

Wolf Creek Mining Co., Fairbanks

Yukon Mining Co., Anchorage

Yukon Placer Mining Co., Fairbanks

Zeiser, Clarence, Poorman

Zimmerman, A. A. \& Peters, Harry,
Near head of Fox Cr.

Gold Run Cr.

Ready Bullion Cr., Ester Dome

Wade Cr., Fortymile Dist.

Bedrock Cr., trib. Cleary $\mathrm{Cr}$.

Atlas Cr., trib. Dahl Cr.

Chicago $\mathrm{Cr}$.

Smith Cr.

Gertrude Cr., Livengood Dist.

Deep Cr., trib. Faith $\mathrm{Cr}$.

Nugget $\mathrm{Cr}$.

Napoleon Cr., trib. Fortymile R.

Little Squaw Cr.

Jump Cr, trib. Candle Cr.

Big Minook \& Hoosier Creeks

Iron Cr., trib. Woodchopper Cr.

Dome Cr.

Kougarok $\mathbf{R}$.

Willow Cr.

Sweepstakes $\mathrm{Cr}$,, trib. Peace $\mathrm{R}$.

Coffee $\mathrm{Cr}$

Woodchopper $\mathrm{Cr}$.

Wolf Cr., trib. Cleary Cr.

Tribs, of Kako Cr.

Fourth of July Cr.

Spruce Cr.

Independence $\mathrm{Cr}$.

$\begin{array}{llr}\text { Fairbanks } & \text { Hydraulic } & 1 \\ \text { C. Nome } & \text { Bulldozer-hydraulic } & 2 \\ \text { Fairbanks } & \text { Gold lode } & 1 \\ \text { Fairbanks } & \text { Bulldozers } & 6 \\ & & \\ \text { Fairbanks } & \text { Gold lode } & 2 \\ \text { C. Nome } & \text { Bulldozer-hydraulic } & 3 \\ \text { Fairhaven } & \text { Coal Mine } & 1 \\ \text { Koyukuk } & \text { Prospecting } & 1 \\ \text { Fairbanks } & \text { Bulldozer-hydraulic } & 2 \\ \text { Fairbanks } & \text { Bulldozer } & 2 \\ \text { Talkeetna } & \text { Hydraulic } & 2 \\ \text { Fairbanks } & \text { Hydraulic } & 1 \\ \text { Fairbanks } & \text { Placer drift } & 2 \\ \text { Fairhaven } & \text { Bulldozer-hydraulic } & 3 \\ \text { Rampart } & \text { Bulldozer-hydraulic } & \\ & \text { (stripping) } & 2 \\ \text { Circle } & \text { Hydraulic } & 1 \\ \text { Eagle } & \text { Bulldozer-hydraulic } & 2 \\ \text { C. Nome } & \text { Dragline-bulldozer } & 4 \\ \text { Wade-Hampton } & \text { Dragline-bulldozer } & 5 \\ \text { Koyuk } & \text { Hydraulic } & 1 \\ \text { C. Nome } & \text { Bulldozer-hydraulic } & 2 \\ \text { Hot Springs } & \text { Placer drift } & 4 \\ \text { Fairbanks } & \text { Hydraulic stripping } & 3 \\ \text { Wade-Hampton } & \text { Dragline } & 6 \\ \text { Eagle } & \text { Bulldozer } & 2 \\ \text { Nulato } & \text { Buldozer stripping } & 2 \\ \text { Circle } & \text { Hydraulic } & 2\end{array}$




\section{LIST OF REPORTS ISSUED BY THE COMMISSIONER OF MINES AND CORRESPONDING PRECEDING OFFICIALS}

"Report of the Mine Inspector for the Territory of Alaska to the Secretary of the Interior, fiscal year ended June 30, 1912

"Report of the Mine Inspector for the Territory of Alaska to the Secretary of the Interior, fiscal year ended June 30,1913

Report of the Mine Inspector for the Territory of Alaska to the Secretary of the Interior, fiscal year ended June 30, 1914.

"Report of the Territorial Mine Inspector to the Governor of Alaska for the year 1915.

Report of William Maloney, Territorial Mine Inspector, to the Governor of Alaska for the year 1916

"Report of the Territorial Mine Inspector to the Governor of Alaska for the year 1917.

Annual Report of the Territorial Mine Inspector to the Governor of Alaska, 1920.

*Amnual Report of the Territorial Mine Inspector to the Governor of Alaska, 1921.

"Annual Report of the Mine Inspector to the Governor of Alaska, 1922

*Annual Report of the Mine Inspector to the Governor of Alaska, 1923

Report upon industrial accidents, compensation and insurance in Alaska for the biennium ending December $31,1924$.

Report of the Territorial Mine Inspector, calendar years 1925-1926

Report of cooperation between the Territory of Alaska and the United States in making mining investigations and in the inspection of mines for the biennium ending March 31, 1929.

Report of cooperation between the Territory of Alaska and the United States in making mining investigations and in the inspection of mines for the biennium ending March 31, 1931.

Mining investigations and mine inspection in Alaska, biennium ending March $31,1933$.

Report of the Commissioner of Mines to the Governor, biennium ending December 31,1936

Report of the Commissioner of Mines to the Governor, biennium ending December 31,1938 .

Report of the Commissioner of Mines to the Governor, biennium ending December 31, 1940.

Joesting, Menry R., Strategic mineral occurrences in interior Alaska: Pamphiet No. 1, May 1942

Joesting, Henry R., Supplement to Pamphlet No. 1-Strategic mineral occurrences in interior Alaska: Pamphlet No. 2, March 1943.

Anderson, Eskil, Mineral occurrences in Northwestern Alaska; Pamphlet No. 5, May 1944.
Stewart, R. I., Prospecting in Alaska (26-page pamphlet), December, 1944. (Revised to November 1949)

Report of the Commissioner of Mines to the Governor, two biennia ended December 31, 1944.

Glover, A. E., Industrial minerals as a field for prospectning in Alaska, including a glossary of eiements and minerals (82-page booklet), March 1945 (Revised to May 1946).

Anderson, Eskil, Asbestos and jade occurrences in the Kobuk River region, Alaska; Pamphlet No. 3, May 1945.

Roehm, J. C., Some high calcium limestone deposits in Southeastern Alaska; Pamphlet No. 6, March 1946

Report of the Commissioner of Mines, biennium ended December 31, 1946. Report of the Commissioner of Mines, biennium ended December 31, 1948. * Out of print-on flle in certain public and university libraries. 